\title{
OSNOVNI PRINCIPI I NAČELA ISLAMSKE EKONOMIJE
}

\section{Sažetak}

Cilj svake države i ekonomskog sistema su materijalni prosperitet naroda $i$ pojedinca. Samo narod kojem se obezbijede osnovni životni uvjeti može razmišljati o visim ciljevima i strategijama. Jedna od glavnih intencija islama je obezbjedenje legalne reprodukcije ljudskog roda i zaštita života na zemlji. Takoder, čovjeku, kao Božijem zastupniku u kosmosu, obezbijediti prikladan život - żivot koji odgovara njegovom položaju i koji će mu pomoći da izvrši svoju osnovnu zadacu zbog koje je poslan i nastanjen na zemlji. Buduci da se ti ciljevi ne mogu ostvariti bez ekonomskog sistema, logično je da islam ima svoj poseban ekonomski sistem i instrumente putem kojih će te ciljeve realizirati. S obzirom na važnost ekonomskog sistema u islamu i pravilo da sredstva uzimaju status ciljeva, tema ovoga rada bazira se na osnovnim principima i načelima islamskog ekonomskog sistema. Cilj studije je da na jedan potpuno jasan i jednostavan način navedem i objasnim osnovne principe islamske ekonomije, cilj i odlike u odnosu na dva najpoznatija ekonomska sistema koji su bili primjenjivani ili se još primjenjuju u savremenom svijetu. Istovremeno, studija je pokušala implicitno i eksplicitno ukazati na nedostatke $i$ razloge zbog kojih ekonomski sistemi koji su do sada primjenjivani i koji se primjenjuju nisu donijeli materijalno blagostanje i sreću čovječanstvu. Takvi sistemi su izbjegnuti ili involvirani u islamski ekonomski sistem, što mu daje svijetlu buducnost i pribvacenost.

Ključne riječi: islam, ekonomija, solidarnost, haram, halal, zarada, imovina, vlasništvo

${ }^{1}$ Islamski pedagoški fakultet u Bihaću. 


\section{Osnovni principi i načela islamske ekonomije ${ }^{2}$}

Svako društvo i zajednica imaju svoj poseban ekonomski pravac koji se reflektuje kroz njegovu filozofiju, doktrinu, vrijednosti, čovjekovu viziju, imovinu i njene svrhe, ideju o vjeri i ovome svijetu, bogatstvu i siromaštvu. Ti faktori opet utječu na stvaranje, razmjenu, podjelu i potrošnju bogatstva, te na taj način nastaje ekonomski sistem jednog društva i naroda.

U ovom radu osvrnut ćemo se na osnovna načela i principe na kojima počiva ekonomija islamskog društva. Najvažnija od njih su:

1- Imetak je dobar u rukama dobrih.

2- Imetak je Allahov, a čovjek je Njegov zastupnik.

3- Poziv na rad i halal zaradu, jer rad je na stepenu ibadeta i džihada.

4- Zabranjuju se stjecanje prljave zarade - imovine.

5- Priznanje privatnog vlasništva i njegova zaštita.

6- Zabranjeno je pojedincima da posjeduju stvari koje su nužne za zajednicu.

7- Zabranjuje se vlasniku imovine da nanosi štetu drugome.

8- Imovina se investira na način da ne šteti moralu i općem interesu.

9- Realizacija stepena životne dostatnosti za cijeli ummet.

10- Umjerenosti u trošenju.

11- Iznalaženje društvene solidarnosti za sve članove društva i zajednice.

\section{Imetak je dobar ali samo u rukama dobrih}

Cilj ovog pravila je definirati imovinske vrijednosti i njihovo mjesto $u$ životu čovjeka. Prije islama, čovječanstvo se susretalo sa mnogo religija i ekonomija. Sve što se odnosi na odmor tijela, njegovo jačanje i snaženje

${ }^{2}$ Rad je u cjelosti naslonjen na poglavlje Ekonomija i imovina od prof, dr. Jusufa Kardavija. Vidi: Jusuf Kardavi, Melamihu mudžteme'il-muslimi ellezi nenšuduhu, str. 189242. Izdavač: Mektebetu Vehbe, prvo izdanje, 1993/1414. Kairo. 
pojedine religije smatraju prljanjem duše i preprekom njenoga kontrolisanja i uzdizanja. To je bilo poznato u filozofiji Brahma u Indiji, kod Mana u Perziji, kao i kod kršćana kroz filozofija kaluđerstva. Suvremeni ekonomski pravci - kapitalizam i komunizam učinili su ekonomiju središtem života, a imovinu bogom čovjeka i zajednice.

Imovina u percepciji islamske ekonomske filozofije izgleda ovako:

- Imovina je nužna životna potreba i temelj života. Uzvišeni je rekao: I rasipnicima imetke, koje vam je Allah povjerio na upravljanje, ne uručujte...(En-Nisa, 5.)

- Imovina je u Kur'anu na nekim mjestima nazvana dobrom... ,i on je, zato što voli bogatstvo - radiša." (El-Adijat, 8.)

- Bogatstvo je blagodat na koju Allah podsjeća Poslanika, a.s., i vjernike.

I siromah si bio, pa te je imućnim učinio? (Ed-Duha, 8.) A ako se bojite oskudice, pa Allah će vas, ako hoće, iz obilja Svoga imućnim učiniti. (EtTevbe, 28.) A da su stanovnici sélā i gradova vjerovali i grijeha se klonili, Mi bismo im blagoslove is neba $i$ iz zemlje slali, ali, oni su poricali, pa smo ih kažnjavali za ono što su zaradili. (El-A'raf, 26.)

- Siromaštvo se smatra iskušenjem i kaznom kojom Allah kažnjava one koji se okrenu od Njega i koji niječu Njegove blagodati. U tom smislu Uzvišeni je rekao: Allah navodi kao primjer grad, siguran i spokojan, kome je u obilju dolazila hrana sa svih strana, a koji je nezahvalan na Allahovim blagodatima bio, pa mu je Allah zbog onoga sto je radio dao da iskusi i glad i strah. (EnNahl, 112.)

- Allahov Poslanik, a.s., je definirao svoju viziju imovine sa sljedećim riječima: „Divan li je dobar imetak kod dobrog čovjeka.“3

Međutim, imovina nije apsolutno dobro ni opće zlo, nego dobro sredstvo u vlasništvu dobrih i obratno. Imetak je sredstvo za zadovoljavanje potreba, pomoć za izvršenje mnogih obaveza - zekata, hadždža i džihada, kao i nužno sredstvo za kultiviranje zemlje. Sve što islam želi je da imetak ne

\footnotetext{
${ }^{3}$ Bilježi ga Ahmed, vjerodostojnim ga smatraju Hakim i Ibn Hibban od Amra b. Asa.
} 
postane božanstvo koje će ljudi obožavati mimo Allaha i da ih ne dovede $\mathrm{u}$ iskušenje. Imetak je stvoren da bude sredstvo, ne da dovede svog vlasnika u situaciju da zaboravi Gospodara i da zagospodari ljudima. To je iskušenje imovine na koje islam upozorava u sljedećem ajetu: $O$ vjernici, neka vas imanja vaša i djeca vaša ne zabave od sjećanja na Allaha. A oni koji to učine, biće izgubljeni. (El-Munafikun, 9.) Bogatstvo i sinovi su ukras u životu na ovome svijetu, a dobra djela, koja vječno ostaju, bice od Gospodara tvoga bolje nagradena i ono u što se čovjek može pouzdati. (El-Kehf, 46.)

Iz navedenih ajeta zaključujemo da nasilje ne nastaje zbog samog bogatstva, nego zbog čovjeka koji umisli da mu drugi ljudi niti Allah dž. š. nisu potrebni.

\section{Imetak je Allahov, a čovjek je u njemu samo Njegov zastupnik}

Drugo pravilo na kome počiva islamska ekonomija: imetak je u biti Allahov, čovjek je samo Njegov zastupnik - opunomoćenik.

O tome jasno svjedoči sljedeći ajet: Vjerujte u Allaha i Poslanika Njegova $i$ udjeljujte iz onoga što vam On stavlja na raspolaganje. (El-Hadid, 7.) Prema tome, Allah je istinski vlasnik imovine, jer je stvorio sve njegove izvore $\mathrm{i}$ resurse i olakšao puteve njegovoga sticanja. On je čak stvorio i čovjeka i kosmos. Allahovo je sve što je na nebesima i što je na Zemlji. (En-Nedžm, 31.) U Allahovoj vlasti su svi na nebesima i na Zemlji. (Junus, 66.) Kažite vi Meni: šta biva sa onim što posijete? Da li mu vi dajete snagu da niče, ili to Mi činimo? (El-Vaki'a, 63-64.)

Stoga se u Kur'anu kaže: Dajte im nešto od imetka koji je Allah vama dao. (En-Nur, 33.) Neka oni koji škrtare u onome što im Allah iz obilja Svoga daje nikako ne misle da je to dobro za njih. (Ali Imran, 180.) Dakle, u navedenim ajetima jasno je da Allah daje Svoj imetak. U odnosu na njega čovjek je samo zamjenik ili zastupnik, ne njegov istinski vlasnik. S obzirom da je čovjek povjerenik i zastupnik, nije mu dozvoljeno pripisivanje imovine i uzimanje zasluga za njeno sticanje, jer je to bonton nevjernika. Vodeći se tim, Karun je govorio: ,, Ovo što imam stekao sam znanjem svojim, tako ja mislim" - govorio je on. (El-Kasas, 78.) 
Isto tako, čovjeku nije dozvoljeno da imetak prigrabi samo za sebe, a da zanemari ostalu čeljad Istinskog Vlasnika imetka i samim tim njegovu istinsku funkciju. Imam Razi u tom smislu je rekao: „Siromasi su Allahova porodica a bogataši Njegovi rizničari jer imetak koji se nalazi u njihovim rukama je Allahov i da ga Allah nije stavi u njihove ruke - posjede ne bi ga imali ni truna. A nimalo nije neobično da vlasnik rekne svom rizničaru: Podaj dio imovine koja se nalazi u tim riznicama Mojim robovima."

Zastupnik je dužan da pri trošenju imovine uvaži sve naredbe vlasnika, da postupa po njegovim naredbama, da se pokori njegovim uputama i savjetima po pitanju čuvanja, investiranja, trošenja i raspodjele imovine. $\mathrm{Ne}$ smije da kaže ono što su rekli stanovnici Medjene Šuajbu, a.s.: "O Šujbe" - govorili su oni - "da li vjera tvoja traži od tebe da napustimo ono čemu su se preci naši klanjali ili da ne postupamo sa imanjima našim onako kako nam je volja? E baš si 'pametan' i 'razuman!!" (Hud, 78.) Mislili su da su oni apsolutni vlasnici svoje imovine i da s njom mogu raspolagati kako hoće, pa makar to bilo i oprečno zdravom razumu, moralu i općem interesu. Postupali su po pravilu: naša je imovina i mi s njom radimo šta želimo. Međutim, islam uči da je konačni vlasnik imovine Allah - daje od Svojih robova kome hoće da bi vidio kako će postupati s njom. Ukoliko se ne budu pridržavali Allahovih propisa, nasilno će im se uzeti ta prava ili će im se uzurpirati pravo na raspolaganje.

Ovim zlatnim pravilom islam je pretekao teoriju sociologa, prema kojoj, imovina ima socijalnu funkciju, a bogataš je službenik u socijalnom sistemu. Ipak, ovo pravilo ne može pretendovati onome što je Kur'an propisao.

\section{Poziv na rad i halal zaradu}

Ovo pravilo proisteklo je iz prvog i na njemu se zasniva. Ako je imetak u viziji islama samo sredstvo za normalan život, za činjenje dobročinstva $\mathrm{i}$ dijeljenje na Allahovom putu, onda je neophodno njegova zarada sukladno Allahovim zakonima i zakonu kauzaliteta. Stoga, islam poziva na rad i trud, a upozorava na nerad i lijenost. Uzvišeni je rekao: On vam je Zemlju pogodnom učinio, pa hodajte predjelima njezinim $i$ hranite se onim što On daje. (El-Mulk, 15.) 
A kad se molitva obavi, onda se po zemlji razidite i Allahovu blagodat tražite. (El-Džum'a, 10.)

Poslanik a.s. je rekao: „Najhalalnija opskrba koju čovjek uopće može pojesti je ona koju zaradi svojim rukama. “4 Allahov Poslanik s.a.v.s. oštro osuđuje traženje od ljudi i kaže: „Čovjek će neprestano tražiti od ljudi sve dok ne dođe ne Sudnji dan, a na licu mu neće biti ni komad mesa. "5 Islam se ne zadovoljava samo pozivanjem na rad, nego tom pozivu dodaje svojstvo obreda i približavanja Allahu čineći ispravan nijet i uvažavajući Allahove granice. U hadisu stoji: „Ukoliko je izišao radi svoje maloljetne djece i to je na Allahovom putu. Ukoliko je izišao radi svojih starih roditelja i to je na Allahovu putu. Ako je izišao radi sebe da se zbrine i to je na Allahovom putu. " ${ }^{6}$ Podstičući na zemljoradnju Poslanik a.s. je rekao: „Svaki musliman koji posije ili posadi nešto pa od njegovih plodova se nahrani ptica, životinja ili čovjek, za sve to će imati dobro djelo - sadaku." Podstičući na trgovinu rekao je: „Pošten i povjerljiv trgovac će biti na Sudnjem danu sa poslanicima, iskrenim i šehidima. "8 Podstičući na stočarstvo rekao je: „Svaki poslanik kojeg je Allah poslao čuvao je ovce. I ja sam ih čuvao Mekkelijama. ${ }^{\text {"9 }}$ A govoreći o industriji naveo im je primjer Davuda a.s. kome je Allah gvožđe u rukama omekšao pa je od njega pravio štitove: „Davud, a.s., je jeo od zarade svojih ruku. “10

Poslanik, a.s. se borio protiv navike kod Arapa - preziranje zanata i ručnih radinosti kao i prošnja i milostinja koju su tražili od plemenskih vođa i glavešina. Pojasnio im je da je svaki koristan posao častan i plemenit bez

\footnotetext{
${ }^{4}$ Bilježi ga Buharija. Vidi: Albani, Sahihul-Džami'i-sagiru, (5546).

${ }^{5}$ Muttefekun alejhi. Vidi: Albani, Sahihul-Džami'i-sagiru, (5816).

${ }^{6}$ Bilježi ga Taberani sa vjerodostojnim lancem prenosilaca kako to navodi Munziri u EtTergibu i Hejsemi u El-Medžme'i, 4/325.

${ }^{7}$ Muttefekun alejhi. Albani, Sahihul-Džami', 5781.

${ }^{8}$ Bilježi ga Tirmizi i ocjenjuje da je dobar - hasen hadis, 1209.

${ }^{9}$ Bilježi ga Buharija od Ebu Hurejre. Vidi: Sahihul-Džami', 5581.

${ }^{10}$ Bilježi ga Buharija od Ebu Hurejre.
} 
obzira kolika neznatna primanja donosio i ma kako ljudi na njega gledali: „Da neko od vas uzme uže i na leđima donese snop drva i proda ih i na taj način ga Allah zbrine, bolje mu je nego da traži od ljudi koji će mu možda dati ili ne dati. “11

Kolektivna obaveza muslimana je da osposobe dovoljan broj kvalifikovanih ljudi za svako zanimanje i službu koja je potrebna društvu i zajednici kako bi mogli biti samostalni - jesti ono što proizvedu, oblačiti ono što otkaju i sašiju, naoružati svoju vojsku sa onim što naprave slijedeći riječi Uzvišenog: A gvožde smo stvorili, u kome je velika snaga i koje ljudima koristi. (El-Hadid, 25.) Riječi velika snaga ukazuje na ratnu industriju, a koristi ljudima na civilnu. Ukoliko se to ne realizuje u praksi, muslimani i njihovi odgovori bit će grješni. Neki islamski učenjaci smatraju da posao i zarada s jedne strane imaju status mubaha - dozvoljenog, a s druge status vadžiba - obligatne obaveze. Imam Ragib u svom vrijednom djelu $E z$ Ziri'atu ila mekarimiš-šeri'a je rekao: „Privređivanje na ovom svijetu i pored toga što se ubraja s jedne strane u mubah stvari, ipak je s druge strane i obligatna dužnost. Čovjek se ne može u potpunosti posvetiti ibadetu sve dok ne realizuje osnovne životne potrebe. Njihovo postizanje po islamu je obligatna dužnost - vadžib, a sve bez čega se ne može upotpuniti tj. izvršiti vadžib je vadžib. Pošto je nemoguće da čovjek realizuje svoje životne potrebe bez truda drugih ljudi, nužno je onda da im to kompenzira svojim trudom putem rada, u protivnom će se smatrati nasilnikom. Ko bude prekomjerno konzumirao plodove rada drugih putem hrane, odjeće, stanovanja, itd., neophodno je da i on njima u istoj mjeri vrati to svojim radom u protivnom će se smatrati nasilnikom i bez obzira da li namjeravali da mu donesu koristi ili ne. Ko želi da konzumira malo njihova rada, treba uzeto od plodova njihova rada također malo i u tom slučaju će biti prihvatljivo da se od njega uzme malo od plodova njegova rada... ali ko od ljudi uzme mnoge koristi, ali im ne dadne nikakvu, nije postupio po kur'anskom ajetu: Jedni drugima pomažite u dobročinstvu $i$ čestitosti... (ElMaide, 2.) A niti se na njega odnosi opće značenje sljedećeg ajeta: $A$ vjernici i vjernice su prijatelji jedni drugima... (Et-Tevbe, 71.) Stoga se osuđuje onaj

${ }^{11}$ Bilježi ga Buharija od Zubejra. 
koji poziva tesavufu i zapostavlja privređivanje, kao i onaj koji ne posjeduje znanje da se uzme od njega, a niti dobro djelo u vjeri da se slijedi. Takav uzima koristi od ljudi i pravi im konkurenciju u nafaki, a nikakvu korist im ne daje. Poslije takvog načina života ne preostaje ništa više do zapostavljanja infrastrukture i povećanja cijena. A dokaz kojim se potvrđuje ružnoća ovakvog ponašanja je to što Allah osuđuje jedenje ličnog imetak prekomjerno i rasipnički. A kakvo je tek onda stanje onoga koji jede na takav način tuđu imovinu, a ne pruža nikakvu kompenzaciju a niti protuuslugu za nju. "12

Dužnost odgovornih je da svakom sposobnom obezbijede prikladan posao putem kojega će zarađivati i zbrinuti sebe i svoju porodicu. Obveza im je da ga školuju i obuče kako bi bio kvalifikovan za obavljanje posla.

Islam podstiče svoje sljedbenike na častan rad i posao. Sve što traži od muslimana je balans između posla za ovozemaljski život i posla za onaj svijet - ravnomjernost između ovoga svijeta i njegove vjere, balans između njegova tijela i srca kako ga potrebe tijela ne bi odvukle od onoga svijeta, a materija od duha.

Uzvišeni je, opisujući dobre koji posjećuju džamije rekao: $U$ džamijama koje se Allahovom voljom podižu i u kojima se spominje Njegovo ime - hvale Njega, ujutro i navečer, ljudi koje kupovina i prodaja ne ometaju da Allaha spominju $i$ koji molitvu obavljaju i milostinju udjeljuju, i koji strepe od Dana u kom će srca i pogledi biti uznemireni. (En-Nur, 36-37.)

Obaveza radnika je da svoj posao izvršava dosljedno i perfektno, jer perfektnost posla je ista vjerska obaveza kao i perfektnost obreda. U vjerodostojnom hadisu navodi se: „Allah je propisao dobročinstvo u svakoj stvari."13 „Allah zaista voli kada neko od vas uradi neki posao da ga usavrši. "14 Društvo je obavezno raditi na tome da svaki radnik dobije

\footnotetext{
${ }^{12}$ Ragib, Ez-Ziri'atu ila mekarimiš-šeri'a, str. 380-381.,verifikacije: Ebul-Jezid El-'Adžmi, Izdavač: Darus-sahve, Egipat.

${ }^{13}$ Bilježi ga Muslim od Šeddada b. Evsa.

14 Bilježi ga Bejheki u djelu Šu'abul-imani od Aiše. A Albani u Sahihul-Džami'is-sagir smatra da je hasen hadis.
} 
pošteno zarađenu platu, da mu ne umanjuje njegovo pravo niti da ga plaća sa zakašnjenjem.

Navodi hadisa su sljedeći: „Dajte radniku njegovu platu prije nego što mu se znoj osuši."

U hadis kudsijje stoji: „Trojicu ću ljudi ja tužiti na Sudnjem danu od koji je i onaj koji unajmi nekoga da mu uradi posao pa ga odradi a on ne isplati zarađenu platu."

\section{Zabranjeno je stjecanje imovine na haram način}

Ovo pravilo štiti prethodno i upotpunjava ga. Zarada koju islam zagovara i priznaje čista je i dozvoljena - halal.

Prljavu zarada je zabranjena, jer islam u osnovi dozvoljava lijepe, a zabranjuje ružne stvari. Prljava zarada je ona koja je stečene putem nasilja, na nepošten način - otimačinom, krađom, prevarom, varanjem na vagi, monopolom, iskorištavanjem potreba ljudi, podcjenjivanjem tuđih stvari. Nepoštenom zaradom smatra se i ona bez uloženog truda ili partnerstva kamate, kocke, bingo, kladionica. Zarada koja je bila protuvrijednost zabranjenoj stvari, smatra se prljavom i nepoštenom - prodaja alkohola, svinja, kipova, zabranjenih pasa. Takvom vrstom zarade smatra se i kompenzacija za nelegalan interes - nadoknade za proricanje sudbine, gatanja, ogledanja, pisanja kamate, rad u barovima i zabranjenim mjestima.

Allahov Poslanik, s.a.v.s. prijeti vatrom onome ko jede haram. „Svako tijelo koje odraste na haramu, najpreče je vatri. “16 Islam ne posvećuje nikakvu vrijednost nijetu, niti daje počast cilju ukoliko je put zarade zabranjen (onaj koji se bavi kamatom da bi s njom napravio džamiju ili osnovao školu za jetime). Poslanik, a.s. je rekao: „Allah je lijep i prima

\footnotetext{
${ }^{15}$ Bilježi ga Ibn Madže od Ibn Omera, Ebu J'ala od Ebu Hurejre, Taberani u El-Evsatu od Džabira i Hakim od Enesa. Albani ga u Sahihul-Džami'is-sagir smatra hasen hadisom. ${ }^{16}$ Bilježi ga Ahmed, Darimi i Ibn Hibban u svom Sahihu, kao i Hakim od Džabira, kako se navodi u Sahihul-Džami'us-sagir, 4519.
} 
samo ono što je lijepo. "17 "Prljavo djelo ne može pobrisati prljavo.“18 Haram u islamu ostaje haram pa makar sudija na osnovu vanjskih dokaza i presudio da nije. Uzvišeni je rekao: Ne jedite imovinu jedan drugoga na nepošten način i ne parničite se zbog nje pred sudijama da biste na grješan način i svjesno dio tude imovine pojeli! (El-Bekare, 188.) U tom smislu je i značenje sljedećeg hadisa: „Vi se kod mene parničite. Možda neki od vas bude rječitiji u dokazivanju pa mu presudim na osnovu onoga što sam čuo. A kome presudim nešto od prava njegova brata neka zna da je to samo dio džehennemske vatre pa neka je uzme ili ostavi. “19 $\mathrm{Na}$ taj način islam je postavio savjest i bogobojaznost kod muslimana - čuvara i garanta njegovoga ekonomskog života. Dakle, ako sudstvo sudi na osnovu vanjskih dokaza, Uzvišeni Allah, kojega se musliman boji, zna suštinu stvari i tajne. Islam je najviše upozorio na izrabljivanje slabih - uzurpacija jetimske imovine, uzimanje imovine od žena, otimanje imovine podanika od strane vladara, radnika od strane poslodavaca, zemljoradnika od strane zemljoposjednika. Islam je strogo upozorio na opasnost bespravnog uzimanja društvene imovine, jer svaki građanin ima pravo na tu imovinu. Kada neko od njih nešto ukrade smatra se otetim od svih i na Sudnjem danu bit će tužen. U tom smislu je došla zabrana i prijetnja za bespravno uzimanja ratnog plijena. U Kur'anu se kaže: A onaj ko nešto utaji-donijeće na Sudnji dan to što je utajio i tada će se svakome u potpunosti dati ono što je zaslužio, nikome se nepravda neće učiniti. (Ali Imran, 161.) Društvena imovina je zabranjena svim službenicima i nije im dozvoljeno bespravno uzeti ni jedan pfennig. Isto tako im nije dozvoljeno da se na ime položaja bogate, jer svako ko ima i najmanje savjesti shvatit će da je to mito i korupcija. Prenosi se da su neki poklonili Omeru b. Abdulazizu nešto pa mu je darovatelj rekao: „Allahov Poslanik, a.s., je primao poklone, našto je on, r.a., rekao: „Pokloni koji su poklanjani Allahovom Poslaniku, a.s., su bili pokloni, a ono što se nama poklanja je mito." Allahov Poslanik, s.a.v.s.,

\footnotetext{
${ }^{17}$ Bilježi ga Muslim od Ebu Hurejre.

${ }^{18}$ Bilježi ga Ahmed i Hakim od Ibn Mesuda.

${ }^{19}$ Bilježi ga Buharija i Muslim. Vidi: El-L'ulu'ul vel-merdžan fima ittefeka alejhiš-šejhan, 1114.
} 
se žestoko rasrdio na svog službenika po imenu Ibn Lutbijje kada mu je došao sa nešto imovine nakon povratka sa službenog putovanja radi prikupljanja zekata. Rekao je: „Ovo je vama a ovo je meni poklonjeno.“ Našto je Poslanik, s.a.v.s., rekao: „Zašto nisi sjedio kod kuće svog oca i majke pa da se vidi da li bi ti neko nešto poklonio ili ne. "20 Dakle, ovom državnom službeniku pokloni nisu dati radi njega lično niti radi sadake ili prethodnog uobičajenog darivanja, nego su mu dati zbog položaja, te on nema prava na njih. Islam je bez sumnje prvi koji je primijenio sljedeća pravila:

\section{Odakle ti ovo?!}

2. Provjera imovine stečene na nelegalan način.

Zabranivši izvore prljave zarade, islam je realizovao nekoliko socijalnih i ekonomskih ciljeva:

- Uspostavio je i osnažio veze među ljudima na osnovu pravde, bratstva, poštivanje harama i davanje svakom pravo koje mu pripada.

- Anulirao je najvažniji faktor koji vodi ka proširenju ekonomskih razlika između pojedinaca i staleža, jer ogromne zarade obično dolaze od slijeđenja zabranjenih puteva pri stjecanju imovine. Slijeđenje legalnih puteva implicira umjerenu i logičnu zaradu.

- Motivisao je ljude na rad i ulaganje napora, jer nije dozvoljeno jesti tuđu imovinu na nedozvoljen način - bez ulaganja rada, protuvrijednosti i učestvovanje u profitu i gubitku. U svemu tome je bez sumnje korist ekonomiji.

\section{Priznanje lične i društvene imovina i njihova zaštita}

Islam je prirodna vjera i u njemu ne postoji nijedan princip ili načelo koji su suprotni ljudskoj prirodi. U njemu su propisi i norme koji odgovaraju ljudskoj prirodi, koji je odgajaju i uzdižu. Ljudskoj prirodi pripadaju ljubav i sklonost za posjedovanjem koju vidimo čak i kod djece, a koja je ispoljavaju bez ikakvog podučavanja i nagovaranja. Uzvišeni Allah podario

${ }^{20}$ Muttefekun alejhi. 
je čovjeku nagon da bude snažan faktor u motivaciji za kretanje, stvaranje i perfekciju kada spozna i stvarno osjeti rezultate svog rada i truda. $\mathrm{Na}$ taj način, život će se bez sumnje razvijati i napredovati; povećavat će se proizvodnja i stvoriti izobilje.

Posjedovanje je jedna od odlika slobode, jer rob ne posjeduje. Samo slobodan čovjek može imati i posjedovati. Posjedovanje je čak jedna od osobina ljudskosti, jer je životinje ne mogu imati. Ta sposobnost data je samo čovjeku. Zbog svega toga, islam je priznao privatno vlasništvo, jer je to prirodna vjera koja poštuje ljudsku prirodu, slobodu i ljudskost. Sloboda nije uskraćivanje čovjeku da uživa u plodovima svog truda i zarade, a koji će se dodijeliti onima koji sjede i ljenčare. Sloboda i pravda se realizuju samo onda kada se svima pruži ista prilika - prilika da privređuju i posjeduju. Ukoliko se neko od njih bude odlikovao svojom inteligencijom, trudom, temeljitosti i upornosti zaslužuje adekvatnu nagradu za to.

Zar nagrada za dobro učinjeno djelo može biti nešto drugo do dobro?! (ErRahman, 60.) Za sve će biti posebni stepeni... (El-Ahkaf, 19.)

$\mathrm{Na}$ osnovu toga, islam dozvoljava posjedovanje imovine, pa makar pojedinac stekao i postao vlasnik ogromnog bogatstva, ali pod uvjetom da ga stekne na halal način. Stečenu imovinu da troši u dozvoljene svrhe, da se ne približava haramu, da ne bude rasipnik, škrtac i nepravedan, te da ne uzima tuđu imovinu na nepošten način, sukladno teoriji islamskog namjesništva. Najbolji primjer pruža poznati ashab Abdurrahman b. Avf, r.a., kada je krenuo iz Mekke, kao i ostali muhadžiri, bez igdje ičega, ne noseći sa sobom ni imovinu niti kuću. Poslanik, a.s., je izvršio bratimljenje između njega i S'ad b. Rebi'e. Rebi'a ponudio mu je pola svoje imovine i razvod od jedne svoje žene kako bi je Abdurrahman mogao oženiti nakon poslijebračnog čekanja - iddeta. Na sve to Abdurrahman mu je rekao: „Neka ti Allah da berićeta u tvojoj porodici i imovini, nego ti meni pokaži gdje je pijaca." Nakon toga je otišao tražeći Allahove blagodati - nafaku po pijacama nad kojima su primat imali medinski jevreji. Bio je veliki ekonomski kapacitet. Za kratko vrijeme je postao jedan od najbogatijih muslimana. Priznavanje privatnog vlasništva i njegove zaštite je bez sumnje dobro za cijeli ummet i njegovu ekonomiju. Dokazano je da privatni 
podsticaji ostvaruju veću proizvodnju od društvene u kojoj je proizvodnja smanjena zbog nepostojanja tih poticaja i jake kontrole koja se nalazi kod privatnog vlasništva. Islam svakom pojedincu dozvoljava privatno vlasništvo, pa čak se može reći da i poziva ka tome. Svakome štiti njegovu imovinu i stavlja je u nasljedstvo potomcima kako bi ga i na taj način podstakao na trud i upornost. $\mathrm{Na}$ taj način privatni vlasnici bi osjetili suverenitet i moć kad god okuse blagodat vlasništva. Islam ne dozvoljava da građani budu robovi države nad kojom vlast ima šačica ljudi, koji ponižavaju ostale, anuliraju vjeru i moral. Istovremeno, većina građana ne posjeduje ništa.

Islam kod zaštite i očuvanja privatne imovine uslovljava dva uvjeta:

1- Utvrđivanje da je stečena po islamu na legalan način, u protivnom neće biti priznata bez obzira koliko vremena bila u vlasništvu onoga koji je posjeduje. Ovdje se islamsko pravo razlikuje od laičkih prava koja priznaju zabranjeno vlasništvo kada nad njim prođe određeni rok - kada zastari deset ili petnaest godina. Islamsko pravo smatra da protok vremena (zastarijevanje) ne može pretvoriti haram u halal ukoliko je zabranjenost potvrđena i poznata.

2- Da ne bude oprečna sa općim interesom u društvu i zajednici, u protivnom će se izuzeti dobrovoljno ili prisilno iz privatnog vlasništva i kompenzirati pravedno, jer se opći interes preferira nad ličnim.

Kada je Omera, r.a., za vrijeme svoje vladavine htio proširiti Harem zbog povećanja broja hadžija, pojedine kuće, koje su bili uz njega, je otkupio dok su vlasnici nekih odbili da ih prodaju. Omer ih je prisilno od njih uzeo, a njihovu vrijednost je stavio u kabensku kasu odakle su je uzeli nakon izvjesnog vremena vlasnici uzurpirani kuća. Ista stvar se desila i za vrijeme Osmana, r.a. Prema tome, ukoliko se javi nužda ili velika potreba da se odredi neko mjesto za gradnju bolnice, fabrike, aerodroma, škole, vlasnik te parcela nema pravo odbiti njenu prodaju. Ako to učini nadležne vlasti će ga prisiliti na presude suda čija je nadležnost rješavanje sporova između države i građana. 


\section{Zabranjeno je pojedincima da posjeduju stvari koje su nužne za društvo i zajednicu}

Najizrazitija razlika među ekonomskim sistemima je njihov odnos prema privatnom vlasništvu. Tako je komunizam apsolutno protiv privatne svojine i nastoji da je svu učini općim vlasništvom, osim u nekim neznatnim stvarima i pokretnom imovinom. Revolucionarni socijalizam ne dozvoljava posjedovanje proizvodnih sredstava poput zemlje i fabrika, te ih nastoji izuzeti i staviti u vlasništvo države koliko god je to moguće. Kapitalizam priznaje vlasništvo nad svim stvarima i skoro da ga ne uslovljava nikakvim uvjetima kako bi zaustavio i ograničio nasilje onih koji ga posjeduju.

Islam je stao negdje na sredini između tih ekonomskih sistema. On dozvoljava privatno vlasništvo nad pokretnom i nepokretnom imovinom, nad sredstvima za proizvodnju, ali ne dozvoljava privatizaciju nužnih stvari koje su potrebne svim ljudima. Vlasništvo nad njima povjerio je društvu kako prevlast ne bi dobili pojedinci ili pojedinac i potpuno ih stavili pod svoju kontrolu. Takvi pojedinci vršili bi monopol i društvene koristi prodavali, nanoseći štetu društvu i zajednici. Kao primjer za status ovih nužnih stvari može se navesti hadis u kojem je Poslanik, a.s., rekao: „Ljudi su partneri u tri stvari: vodi, pašnjacima i vatri. “21

Svaki čovjek ima pravo da koristi prirodne resurse i nikome nije dozvoljeno da ima monopol nad njima. Hadis nije specificirao samo navedene tri ili četiri stvari zbog toga što su bile u to vrijeme najpoznatije nužnosti. $\mathrm{Na}$ osnovu analogije moguće je dati isti status i ostalim stvarima koje su nužne ljudima u svakom društvu i zajednici.

U tom kontekstu malikije, po mišljenju mezheba, smatraju da se izvađena ruda iz zemlje ne može dati u privatno vlasništvo pa makar se rudnik našao na privatnom posjedu. Isto se prenosi od šafija i hanbelija - svaki javni izvor minerala ili rudnik metala poput nafte, dragog kamenja, sumpora, koji se nađu na ničijoj zemlji, nije dozvoljeno prisvojiti.

${ }^{21}$ Bilježi ga: Ebu Davud a Ibn Madže je dodao još i „so“. 


\section{Zabranjeno je vlasniku da nanosi štetu drugome}

I pored toga što je islam dozvolio privatno vlasništvo, osim nad onim što je nužno za sve ljude, ipak je postavio neka ograničenja na to pravo kako bi ostalo u okvirima interesa društva i u službi istine i dobra. Od tih pravila je i zabrana vlasniku privatne imovine da pri njenom korištenju nanese štetu drugom. Prema tome, vlasnik privatne imovine nije apsolutno slobodan pri raspolaganju s njom, stoga ne smije nanositi štetu drugima. Nanošenje štete i uzvraćanje na štetu štetom, muslimanu nije dozvoljeno. Islam uči muslimana da bude izvor dobra, a ne štete. Poslanik, a.s., je rekao: „Nema nanošenja štete a niti uzvraćanja na štetu štetom. ${ }^{\text {“22 }}$

Dužnost je nadležnih spriječiti vlasnika privatne imovine od svakog egoističnog postupka koji implicira ličnu ili opću korist pa makar to zahtijevalo i uzurpaciju privatne imovine. Ovaj princip, za koga neki pravnici misle da je produkt savremenog doba, Poslanik, a.s., je primjenjivao petnaest stoljeća, a poslije njega su ga primjenjivale $\mathrm{i}$ pravedne halife.

Semure b. Džundub je imao palme u voćnjaku nekog Medinlije pa je sa porodicom ulazio u njega. To je uznemiravalo vlasnika voćnjaka pa se na to požalio Poslaniku, a.s. Poslanik, a.s., je rekao Semuri: „Prodaj mu te palme." Međutim, on odbije da to učini. "Izvadi ih i presadi na drugo mjesto", rekao mu Poslanik, a..s, drugog puta. I to odbi da učini. "Podari ih meni imat ćeš iste u džennetu", reče mu Poslanik, a.s. I to je odbio. Nakon toga je Poslanik, a.s., rekao: „Ti si onaj koji nanosiš štetu“, a ensariji navodi: „Idi i počupaj mu palme.“223 Dakle, Poslanik, a.s., se nije obazirao na malu štetu nanesenu Semuri u odnosu na štetu koju nanosi vlasniku ostavljajući palme na sred voćnjaka. Semure je mogao da proda nekoliko palmi vlasniku voćnjaka i da dobije pravednu nadoknadu. Isto tako mogao ih je presaditi na drugo mjesto gdje ne bi nikome smetao. Kako spor nije

\footnotetext{
${ }^{22}$ Bilježe ga Ahmed i Ibn Madže od Ibn Abbasa. Ibn Madže ga bilježi i od Ubade. Vidi: Sahihul-Džami'us-sagir, 7517.

${ }^{23}$ Bilježe ga Ebu Davud, 3636. i Bejheki, 6/157., od Semure. U lancu prenosilaca mu postoji prekid.
} 
riješen na mirnodopski način, Poslanik, a.s. je naredio da se palme počupaju bez obzira da li njihov vlasnik s tim bio zadovoljan ili ne.

Za vrijeme Omera, r.a., Dahhak b. Halifa je imao zemlju do koje nije stizala voda za navodnjavanje osim preko zemlje Muhammeda b. Mesleme. Dahhak je htio iskopati jarak kako bi do svoje zemlje doveo vodu, ali mu Muhammed to nije dozvoljavao. Dahhak požalio Omeru, r.a., a on je potom pozvao Muhammeda i popričao s njim o tome. Međutim, Muhammed je ostao pri svome stavu. Omer je nakon toga rekao: „Zašto zabranjuješ svom bratu ono što će mu koristiti a i tebi je od koristi?! Zalijevaćeš i prvi i posljednji a ne šteti ti?!" Muhammed je rekao: „Ne tako mi Allaha.“ Omer mu je na to rekao: „Tako mi Allaha ona će proći pa makar i preko tvog stomaka. “24 I naredio je Dahhaku da sprovede naredbu. Iz navedenog primjera zaključujemo da nije dozvoljeno neprimjereno ponašanje prema komšijama i partnerima. Takvo ponašanje nije dozvoljeno ni prema onima koji imaju direktnu vezu sa privatnim posjedom, pod izgovorom da je neko potpuno slobodan u onome što raspolaže, jer ta sloboda je ograničena principom - Nema štete niti sa na štetu dogovara štetom.

Allahov Poslanik, s.a.v.s., zabranio: „Neka komšija komšiji ne zabranjuje zabijanje drveta u njegov zid. “25

\section{Imovina se treba investirati na način da ne šteti moralu niti općem interesu}

Islam poziva bogataše da svoju imovinu oplođuju i investiraju, dok zabranjuje njenu deponuju - zaleđivanje i nekorištenje u svrhe radi kojih je i stvorena. Tako zemljoposjedniku nije dozvoljeno da zapusti zemlju i ostavi je neposijanu posebno onda kada su društvu i zajednici potrebni njeni usjevi i plodovi. Ista je stvar i sa vlasnikom fabrike za čijim

\footnotetext{
${ }^{24}$ Bilježe ga: Malik, 2/746., od njega ga prenosi Šafija, 2/34. i Bejheki, 6/157. Prenosioci su mu vjerodostojni, s tim što je mursel kako navodi Bejheki.

${ }^{25}$ Bilježe ga Buharija i Muslim od Ebu Hurejre i Ibn Madže od Ibn Abbasa. Vidi: SahihulDžamis-sagir, 7784.
} 
proizvodima ljudi imaju potrebe, jer je to oprečno principu zastupništva el-istihlafa. Onima koji imaju pare nije dozvoljeno da ih rizniče i upotrebljavaju, a ljudima su potrebni korisni projekti putem kojih će se zaposliti, pokrenuti ekonomiju i podići životni standard. Stoga ne čudi što Kur'an žestoko prijeti egoističnim rizničarima u sljedećem ajetu:

Onima koji zlato i srebro gomilaju i ne troše ga na Allahovom putu - navijesti bolnu patnju na Dan kad se ono u vatri džehennemskoj bude usijalo, pa se njime čela njihova i slabine njihove i leđa njihova budu žigosala. "Ovo je ono sto ste za sebe zgrtali; iskusite zato kaznu za ono što ste gomilali!" (Et-Tevbe, 34-35.) Posjedovanje imovine pri investiranju i oplođavanju, islam ograničava sa šerijatskim načinima koji se ne kose sa moralom i uzvišenim etičkim vrijednostima, niti sa općim interesom. Glavnica u islamu nije slobodna kao u kapitalističkom sistemu kako je to davno mislio Šuajbov narod. "O Šuajbe" - govorili su oni - "da li vjera tvoja traži od tebe da napustimo ono čemu su se preci naši klanjali ili da ne postupamo sa imanjima našim onako kako nam je volja? E baš si 'pametan' i 'razuman'!" (Hud, 87.)

Zbog toga je islam pri oplođavanju imovine zabranio sljedeće metode i sredstva:

\section{a- Kamatu:}

gdje lihvar koristi potrebu onoga kome je novac nužan, pa mu nameće višak kojeg uzima bez ikakve protunaknade - uloženog truda ili rizika. $\mathrm{Na}$ taj način se povećava bogatstvo bogataša i siromaštvo siromaha i stvara se stalež poput pijavice koja siše krv radnika i poduzetnika, a ne radi ništa. $\mathrm{Na}$ taj način se povećavaju ekonomske razlike među staležima i potpaljuje vatra srdžbe, sukoba i mržnje. Islam je strogo zabranio kamatu i nagovijestio najtežu kaznu za lihvare:

O vjernici, bojte se Allaha $i$ od ostatka kamate odustanite, ako ste pravi vjernici. Ako ne učinite, eto vam onda, neka znate - rata od Allaha i Poslanika Njegova! A ako se pokajete, ostaće vam glavnice imetaka vaših, nećete nikoga oštetiti, niti ćete oštećeni biti. (El-Bekare, 278 - 279.) 


\section{b- Monopol:}

U vjerodostojnim hadisu stoji: „Monopol čini samo onaj koji griješi.“" Onaj koji je grješnik. U drugom hadisu kojeg bilježi Ahmed stoji: „Ko bude četrdeset dana monopol vršio nad hranom takav nema ništa $s$ Allahom a niti s Poslanikom, s.a.v.s. " ${ }^{27}$ Ova prijetnja je izrečena zbog toga što monopolista želi da izgradi sebe na tuđim ruševinama i dok god ima koristi od toga, ne zanima ga da li će ljudi biti gladni, bosi ili goli. Kad vidi da se potreba ljudi poveća, on sve više skriva robu, a radost je veća zbog poskupljenja.

Zbog toga se u hadisu navodi: „Loš li je čovjek monopolista kada čudne da je roba pojeftinila to ga rastuži a kada čudne da je poskupila to ga obraduje." 28

Islamski pravnici nemaju jedinstven stav po pitanju robe koju je zabranjeno monopolisati:

Da li su to živežne namirnice ili sve ono što je nužno za ljude?

Najispravnije je ono što zastupa Ebu Jusuf - sve što njegovim uklanjanjem nanosi štetu smatra se monopolom.

\section{c- Prevara:}

Prevara je u svakom obliku islama zabranjena. U hadisu stoji: „Ko vara nije od nas. “29 „Ugovarači imaju pravo izbora sve dok se ne raziđu. Pa ako budu iskreni i otvoreni daće im se berićet u kupoprodaji, a ako šta sakriju i slažu berićet će biti poništen u njihovoj kupoprodaji. " $30 \mathrm{U}$ prevaru se ubraja varanje na vagi i kantaru, o čemu se jasno govori i u Kur'anu: Teško onima

\footnotetext{
${ }^{26}$ Bilježe ga: Muslim, Ebu Davud, Tirmizi i Ibn Madže.

${ }^{27}$ Bilježi ga Ahmed od Ibn Omera. Šejh Šakir ga smatra vjerodostojnim broj: 4880

${ }^{28}$ Naveo ga je Rezin u svom Džami'u.

${ }^{29}$ Bilježe ga: Muslim i drugi od Ebul-Hamre i Ibn Mesuda. Vidi: Sahihul-Džami', 64066408.

${ }^{30}$ Muttefekun alejhi od Hakima b. Huzama kako se navodi u Sahihul-Džami'u.
} 
koji pri mjerenju zakidaju, koji punu mjeru uzimaju kada od drugih kupuju, a kada drugima mjere na litar ili na kantar - zakidaju. ${ }^{31}$

\section{d- Trgovina sa zabranjenim - haram stvarima:}

Pod zabranjenim stvarima podrazumijevaju se one koje po islamu zabranjeno koristiti i prodavati - drogu, svinjetinu, zlatno i srebreno posuđe, kipove, ikone, pokvarenu hranu.

e- Sve što je oprečno moralnim principima i vrijednostima:

što udaljuje od vjere i šteti općem interesu u islamu ima status zla.

\section{Realizacija i ostvarenje ekonomske neovisnosti ummeta}

Od načela islamske ekonomije je realizacija i ostvarenje ekonomske neovisnosti islamskog ummeta. Pod tim se podrazumijeva da je vjerska obaveza islamskog ummeta posjedovanje iskustva, kvalifikacije, sredstva i tehniku koja će ga učiniti moćnim da proizvede onoliko koliko će zadovoljiti materijalne, duhovne, civilne i vojne potrebe. To se sve treba realizirati putem institucije kolektivnih obaveza - el-furudul-kifaje. Ova institucija obuhvata sve nauke, poslove, proizvodnje i vještine koje su potrebne ljudima u ovozemaljskom životu i vjeri. Vjerska obaveza muslimana je da ih nauče, podučavaju i usavrše kako ne bi zavisili od drugih i kako s njima ne bi upravljali drugi. Bez te neovisnosti $\mathrm{i}$ samostalnosti neće se moći realizovati ponos koji im je Allah propisao u Kur'anu: A snaga je u Allaha i Poslanika Njegova i u vjernīkā... (ElMunafikun, 8.) Bez toga neće moći ostvariti samostalnost i istinski suverenitet koji je spomenut u sljedećem ajetu: A Allah neće dati priliku nevjernicima da unište vjernike. (En-Nisa, 141.) Niti će se ispuniti liderstvo i svjedočenje protiv drugih naroda: I tako smo od vas stvorili pravednu zajednicu da budete svjedoci protiv ostalih ljudi, i da Poslanik bude protiv vas svjedok. (El-Bekare, 143.)

Prema tome, nijedan narod čije je oružje proizveo neko drugi, pa mu ga prodaje kada hoće i pod uvjetima koje želi, ne može imati ponos. Niko ne

${ }^{31}$ Muttefekun alejhi. 
može imati istinski suverenitet ako se oslanja na strane stručnjake u najspecifičnijim, najpreciznijim i najvažnijim stvarima. Nijedna država ne može biti samostalna ukoliko ne proizvodi dovoljnu količinu hrane za svoje stanovništvo, ako nema lijekova za svoje bolesnike i ako nema teške industrije pa je prisiljena da istu uvozi. Jedan narod ne može biti u svojstvu lidera ukoliko svoju misiju ne ispuni putem printanih, akustičkih ili vizuelnih sredstava.

\section{Metode putem kojih se postiže neovisnost}

Državna neovisnost se postiže putem nekoliko metoda, a najpoznatije su:

\section{1 - Neophodno planiranje}

Neophodno je da planiranje bude zasnovano na preciznoj statistici, istinskim brojkama, neophodnoj spoznaji o potencijalnim potrebama, njihovim stepenima i važnosti, kao i postojećim ambicijama i sredstvima za realizaciju potreba. Kur'an nam je naveo primjer petnaestogodišnjega planiranja kojeg je sproveo Allahov Poslanik, Jusuf, a.s. Sa tim planiranjem, koje je obuhvatilo proizvodnju, štednju, potrošnju i podjelu, suprotstavio se gladi i sušnim godinama koje su zadesile Egipat i njegovu okolinu.

\section{2- Priprema ljudskih resursa i njihova pravilna raspodjela}

Vjerska dužnost ummeta je da usavrši svoj obrazovni i strukovni sistem koji će biti u mogućnosti obezbijediti snagu i različite ljudske resurse na svim segmentima. Jedna od vjerskih dužnosti je i razvijoj administrativnofinancijskog sistema koji će pravilno i pravedno mobilisati resurse i podijeliti ih na specijalnosti sukladno riječima Uzvišenog: Svi vjernici ne trebaju ići u boj. Neka se po nekoliko njih iz svake zajednice njihove potrudi da se upute u vjerske nauke i neka opominju narod svoj kad mu se vrate, da bi se Allaha pobojali. (Et-Tevbe, 122.)

Svakog čovjeka treba staviti na mjesto koje mu odgovara i paziti da se stvari ne predaju onima koji ih ne zaslužuju. „Kada se stvari predaju onima koji 
im nisu dostojni očekujte Sudnji dan. “32 Stoga islam pazi na ljudske potencijale, čuva ih i razvija: tjelesno, intelektualno, duhovno, praktično, strukovno, itd. Na taj način se postiže balans između vjere ovoga svijeta bez ikakvog nasilja ili gubitka.

\section{3- Pravilno iskorištavanje postojećih resursa}

Treba pravilno iskorištavati ekonomske izvore i materijalne mogućnosti kako se ništa ne bi upropastilo ili bespotrebno bacilo. Svaka blagodat se treba čuvati s obzirom da je emanet. Potrebno se na njoj zahvaliti i upotrijebiti je u prave svrhe. Zbog toga nas je Kur'an upozorio na ono što nam je potčinjeno na nebesima i zemlji, moru i kopnu. Žestoko se okomio na one koji upropaštavaju životinjski i biljni svijet, slijedeći mišljenja za koja Allah nije objavio nikakav dokaz. Takvi su zabranili ono sa čime ih je Allah opskrbio i lagali na Uzvišenog Allaha. O tome se raspravlja u suri El-Ena'm.

Oni govore: "Ova i ova stoka i ti i ti usjevi su zabranjeni, smiju ih jesti samo oni kojima mi dozvolimo" - tvrde oni - "a ove i ove kamile je zabranjeno jahati." Ima stoke prilikom cijeg klanja ne spominju Allahovo ime, izmišljajući o Njemu laži. A On će ih, sigurno, zbog onoga što izmišljaju kazniti. Oni govore: "Ono što je u utrobama ove i ove stoke dozvoljeno je samo muškarcima našim, a zabranjeno ženama našim. A ako se plod izjalovi, onda su u tome sudionici." - Allah će ih za neistine njihove koje oni pričaju kazniti, On je Mudri i Sveznajući. Oni koji iz labkoumnosti i ne znajući šta rade djecu svoju ubijaju i koji ono čime ih je Allah podario zabranjenim smatraju, govoreći neistine o Allahu, sigurno će nastradati. Oni su zalutali i oni ne znaju sta rade. (El-En'am, 38-40.)

Poslanik, a.s., je upozorio na potrebu iskorištavanja svake sirovine i zabranu njenog upropašćivanja pored toga što je ljudi smatraju bezvrijednom. Jedne prilike je prošao pored uginule ovce i upitao za nju. Rekli su mu da ovca pripada oslobođenoj robinji Poslanikove žene Mejmune, na šta je pitao: „Zbog čega niste uzeli njenu kožu i okoristili se

${ }^{32}$ Bilježi ga Buharija od Ebu Hurejre. 
s njom?! Samo je zabranjeno njene meso. " ${ }^{33}$ Poslanik, a.s., upozorava čak i na zanemarivanje jednog zalogaja koji spadne sa sofre ili stola. Hranu treba uzeti, očistiti od prljavštine, pojesti i ne ostavljati šejtanu. Isto tako preporučuje da se posude obližu i da se ostaci hrane ne bacaju u smeće. Ovdje treba posebno istaći Poslanikovo, a.s., podsticanje na sijanje zemlje od strane onih koji to mogu sami raditi ili je unajmiti drugom koji je može obrađivati. U jednom hadisu stoji: „Ko bude imao zemlje neka je sije ili neka je podari svom bratu. “34 Kao vid potpomaganja između zemljoposjednika i seljaka - el-mudareba smatra se sijanje zemlje za procent njenih proizvoda. Poslanik, a.s., je dao Jevrejima da siju hajbersku zemlju za polovinu proizvedenih plodova. Omer b. Abdulaziz je rekao: „Sijte zemlju za pola, trećinu, četvrtinu... desetinu njenih plodova, samo je ne ostavljajte neposijanu."

Poslanik, a.s., je žestoko osudio onoga koji je bespravno ubio vrapca i rekao da će vrabac na Sudnjem danu svoga ubicu tužiti Allahu, govoreći: „Moj Gospodaru, ubio me je bespotrebno a ne iz potrebe. " ${ }^{35}$ Isti status vrapca imaju sve dozvoljene - mubah stvari koje se love, svi kopneni i vodeni resursi. Islam ne dozvoljava uništavanje i iskorjenjivanje, ako u tome nema opće koristi. U vjerodostojnom hadisu stoji da je neki čovjek uzjahao kravu pa je ona progovorila i rekla: "Nisam ja za ovo stvorena, ja sam stvorena za oranje." Da li je krava stvarno govorila ili svojim ponašanjem aludirala?! Odgovor nalazimo u rečenici: Allah može sve! Najvažnije je da hadis ukazuje na to da se stvari trebaju upotrebljavati samo za ono za šta su stvorene.

Društvena imovina ima status imovine jetima. Država koja štiti društvenu imovinu i čije institucije su odgovorne za nju slična je staratelju jetima. Tako je Omer, r.a. uporedio sebe, u odnosu na državnu kasu, sa imovinom jetima koju ne smije jesti ukoliko bude bogat. Ako bude siromašan uzet će

\footnotetext{
${ }^{33}$ Muttefekun alejhi.

${ }^{34}$ Muttefekun alejhi.

${ }^{35}$ Bilježe ga Ahmed i Nesai.
} 
samo onoliko koliko mu je potrebno. Stroga obaveza je da se ta imovina čuva i oplođuje na najljepši način.

\section{4- Ustrojstvo različitih sektora proizvodnje}

Neophodno je da se napravi ustrojstvo među različitim sektorima proizvodnje tako da jedan ne ide na račun drugoga. Nije dozvoljeno da se sva pažnja posveti poljoprivredi, a istovremeno zanemari industrija ili obratno. Također, zabranjeno je stavljanje fokusa na školovanje ljekara, zanemarujući izobrazbu inženjera ili obratno.

Kod proizvodnje neophodno je preferirati nužne stvari nad potrebnim, potrebne nad poželjnim, poželjne nad upotpunjujućim. Stoga država ne smije sijati skupocjeno voće koje mogu kupit samo bogati na račun sijanja pšenice, kukuruza, riže -osnovnih životnih namirnica te populacije. Isto tako ne smiju se proizvoditi mirisi, ukrasi, šminka na račun proizvodnje poljoprivrednih mašina, auta, oružja za odbranu domovine.

Proizvodi koji su štetni, kako za pojedinca tako i za zajednicu, bilo to $\mathrm{u}$ materijalnom ili nematerijalnom, tjelesnom ili duhovnom smislu, islam apsolutno zabranjuje (npr. sijanje grožđa radi cijeđenja vina, sijanja raznih droga, duhana.) Zabranjeno je sve što Božije blagodati koristi u svrhu neposlušnost Allahu ili nanosi štetu Njegovim stvorenjima.

\section{5- Stavljene u opticaj - investiranje novca - keša}

Muslimani u muslimanskom društvu dužni su da izvade pare iz ,jastuka“ i da ga stave u opticaj, jer one nisu stvorene da se skrivaju i rizniče, nego da se obrću iz ruke u ruku. Uzvišeni Allah je propisao svake godine zekat na novac, bez obzira da li se on investirao ili stajao na gomili.

\section{Umjerenost u trošenju}

Islam se uveliko zanima i za način trošenja i podstiče na umjerenost $\mathrm{u}$ svemu, pa i u trošenju. To je svojstvo sa kojim je Uzvišeni opisao Svoje robove i rekao: I oni koji, kad udjeljuju, ne rasipaju i ne škrtare, već se u tome drže sredine. (El-Furkan, 67.) Isto tako je to naredio i u mudrim kur'anskim zapovijedima: Ne drži ruku svoju stisnutu, a ni posve otvorenuda ne bi prijekor zaslužio i bez ičega ostao. (El-Isra, 29.) U jednom hadisu 
Poslanik, a.s., je rekao: „Hrana za jednog dovoljna je dvojici, a hrana za dvojicu dovoljna je za četvericu. “36 Dakle, islam muslimanu ne zabranjuje lijep život kao što to rade druge religije i filozofije, zabranjuje samo pretjerano uživanje i raskoš pri njegovu konzumiranju. Uzvišeni je rekao: O vjernici, ne uskraćujte sebi lijepe stvari koje vam je Allah dozvolio, samo ne prelazite mjeru, jer Allah ne voli one koji pretjeruju. (El-Maide, 87.) I siromahu, i putniku, ali ne rasipaj mnogo jer su rasipnici braća šejtanova, a šejtan je Gospodaru svome nezahvalan. (El-Isra, 26-27.)

Razlika između tebzira i israfa je u tome što israf znači pretjerivanje u halalu, a tebzir trošenje imetka u haramu. Stoga je obavezno uvažavati sljedeće principe pri trošenju imovine:

\section{a- Trošenje na sebe i porodicu}

Vlasniku imovine nije dozvoljeno da škrtari i ne izvršava svoje materijalne obaveze prema sebi i porodici. Islam zabranjuje škrtost i upozorava na nju i smatra je izvorom nereda širokih razmjera. U jednom hadisu stoji: „Čuvajte se škrtosti jer su zbog nje propali oni koji su bili prije vas. Ona im je nalagala da pokidaju rodbinske veze pa su to i učinili, naredila im je škrtarenje pa su ga prihvatili i naredila im je nemoral pa su ga upražnjavali. “37

Isto tako, islam zabranjuje kaluđerstvo i uskraćivanje halal uživanja. Lijepu odjeću, ukusna jela i ostalo naziva ukrasima: Reci: "Ko je zabranio Allahove ukrase, koje je On za robove Svoje stvorio, i ukusna jela?"(El-A'raf, 32.) S druge strane, žestoko osuđuje sve one koji te blagodati sebi i drugima zabranjuju i uskraćuju: Reci: "Ko je zabranio Allahove ukrase, koje je On za robove Svoje stvorio, i ukusna jela?"(El-A'raf, 32.) O sinovi Ademovi, lijepo se obucite kad hoćete molitvu obaviti! I jedite i pijte, samo ne pretjerujte; On ne voli one koji pretjeruju. (El-A'raf, 31.)

\footnotetext{
${ }^{36}$ Bilježi ga Muslim i drugi od Džabira.

37 Bilježe ga Ebu Davud u skraćenoj verziji, br. 1698., Hakim, 1/11 a Zehebi ga je prešutio.
} 
Allahov Poslanik, a.s., je rekao: „Uistinu Allah voli vidjeti na Svom robu tragove Svoje blagodati. “38 A kada mu je jedan od ashaba rekao da voli biti sređen jer voli da mu odjeća i obuća budu lijepi pa da li se to smatra ohološću? Rekao je: „Allah je lijep i voli ljepotu, a oholost je odbijanje istine i omalovažavanje ljudi. “39

\section{b- Obaveza je trošiti imovina na obligatne obaveze}

Vlasnik imovine ne smije škrtariti kada su u pitanju primarne materijalne obaveze bez obzira da li su konstantne - zekatt, izdržavanje roditelja i siromašne rodbine ili povremene -ugošćavanje gostiju, pozajmljivanje potrebnih stvari, pomaganje u nevoljama poput ratova, poplava, gladi, suša, požara, itd. Islam potvrđuje važnost tih prava tako što dozvoljava čak i objavu rata zbog njihovog kršenja. Ebu Bekr i ashabi su poveli rat zbog nedavanja prava zekata. Poslanik, a.s., je dozvolio gostu da uzme svoje potrebe - prava gdje god da zanoći, pa makar i silom. U tom smislu je rekao: „Koji god gost zanoći u nekom narodu pa mu uskrate gostoprimstvo, ima pravo da uzme svoje potrebe i u tome mu se neće ništa zamjeriti. "40 Većina islamskih pravnika dozvoljava onome ko se nađe u nuždi za vodom i hranom da se bori protiv svakog ko pokuša da mu ih zabrani.

\section{c- Balansiranje između prihoda i rashoda}

Dužnost svakog muslimana je da napravi balans između svojih prihoda i rashoda - da ne troši deset maraka, a zarađuje osam i na kraju bude prisiljen uzeti kredit i bespotrebno postati dužnik. A dug je, kako kaže poslovica, noćna briga, a dnevno poniženje. Poslanik, a.s., se utjecao Allahu da ga sačuva duga, jer kada se čovjek zaduži počne previše pričati, lagati, obećavati i ne ispunjavati obećanja, kako se to navodi u Sahihu od Buharije. Trošenje u većem iznosi od prihoda i više nego što to može

\footnotetext{
${ }^{38}$ Bilježi ga Tirmizi od Amra b. Šuajba od njegova oca i djeda i veli da je hasen - dobar.

${ }^{39}$ Bilježi ga Muslim od Ibn Mesuda.

${ }^{40}$ Bilježi ga Ahmed od Ebu Hurejre. Munziri je rekao u svom djelu Et-Tergibu i Hejsemi u El-Medžmi', 8/147., da su prenosioci vjerodostojni. Isto tako je bilježi i Hakim i veli daje vjerodostojan u čemu se s njim složio i Zehebi, 4/132.
} 
izdržati nečija imovina se smatra pokuđenim rasipništvom. Uzvišeni je rekao: Samo ne pretjerujte; On ne voli one koji pretjeruju. (El-A'raf, 31.)

U jednom hadisu Poslanik, a.s., je rekao: „Jedite, pijte, oblačite se i dijelite sadaku samo da ne bude u tome pretjeranosti i oholosti." Hadis bilježi Nesai i Ibn Madže od Amra b. Šua'jba od njegova oca i djeda. On se odnosi na trošenje na dozvoljene stvari; na zabranjene je haram potrošiti bilo šta. Što se tiče trošenja u dobrotvorne svrhe - sadaka, džihad, dobrotvorni projekti, u tome nema pretjerivanja sve dok se putem njih ne zanemari veća obaveza -izdržavanje porodice, vraćanje duga dužniku ili neko drugo obavezno izdržavanje. Kada je darežljivim dobročiniteljima rečeno da nema hajra u raskoši, odgovarali bi im da nema raskoši u dobru.

Isto tako treba istaći da islam daje pravo nadležnim da izuzmu pravo na posjedovanje imovine svakom rasipniku koji bespotrebno uništava imovinu. Njegova očuvanost i zaštita bez sumnje donosi korist cijelom ummetu, a uništenje štetu. Stoga je Uzvišeni imovinu rasipnika pripisao ummeta i rekao: I rasipnicima imetke, koje vam je Allah povjerio na upravljanje, ne uručujte. (En-Nisa, 5.)

\section{Rat protiv raskoši i raskošnika}

Islam zabranjuje raskoš kao vrstu rasipništva, ukazavši na njegovu opasnost s obzirom da kvari pojedince, društva i zajednice. Kur'an raskoš smatra prvom preprekom koja sprečava ljude da slijede istine, jer raskoš raskošnicima ne ostavlja prostora nizašto drugo osim za strasti i uživanja. Stoga će se suprotstaviti svakom ko ih bude pozivao ka nečemu drugom. Uzvišeni je u tom smislu rekao: Mi ni u jedan grad nismo poslanika poslali, a da nisu rekli oni koji su na raskošan život bili navikli: "Ne vjerujemo mi u ono što je po vama poslano!" (Sebe', 34.)

Raskoš također implicira igre, razonodu i zabave i utječe na širenje moralne opuštenosti i bezbrižnosti kod omladine. Nakon izvjesnog vremena vodi ka uništenju morala ummeta, slabljenju međusobnih veza među muslimanima i širenju staleških razlika u društvu. Zbog toga cijelo društvo i zajednica zaslužuju da budu uništeni i kažnjeni. Raskošnici zbog svoga raskoša, a drugi zbog indolentnoga odnosa i prešućivanja svega toga. Kad 
hoćemo jedan grad unistiti, onima koji su u njemu na raskoš navikli prepustimo da se razvratu odaju i da tako zasluže kaznu, pa ga onda do temelja razrušimo. (El-Isra, 16.) Poruka Kur'an je da je raskoš bio glavni razlog zbog kojega je neke narode zadesila odgovarajuća Allahova kazna. $A$ kada smo na muke stavili one među njima koji su raskošnim životom živjeli, oni su odmah zapomagali. "Sada ne zapomažite, Mi vam nećemo pomoć ukazati. (El-Mu'minu, 64-65.)

A koliko je bilo nevjerničkih sela i gradova koje smo uništili i poslije kojih smo druge narode podigli! I čim bi silu Našu osjetili, kud koji bi se iz njih razbježali. "Ne bježite, vratite se uživanjima vašim i domovima vašim, možda ce vas neko što upitati." (El-Enbija, 11-13.)

\section{Umjerenost u državnom trošenju}

Ako se traži umjerenost u trošenju kada je u pitanju pojedinac - građanin musliman, onda se ona traži i od države i državnih troškova počevši od predsjednika države pa do najmanjeg činovnika. Čak bi lider muslimana trebao biti uzor ostalima u skromnosti i trošenju državnog novca.

Poslanik, a.s., kao vođa muslimana bi prvi osjećao glad, a zadnji bi je utolio. Ebu Hurejre je rekao: „Allahov Poslanik, s.a.v.s., je napustio ovaj svijet, a da se nikada nije najeo ječmena hljeba.“" ${ }^{41}$ Aiša je rekla: „Nikad Poslanik, a.s., nije bio uzastopno sit tri dana, a da smo htjeli mogli smo biti siti, ali je davao drugima prednost nad sobom. ${ }^{\text {"42 }}$ Isto tako nije prihvatio da spava na mehkom dušeku. Jastuk mu je bio od palminog lišća, oblačio je grubu i jednostavnu odjeću, a spavao na hasuri koja je ostavljala tragove na bokovima. Istu sudbinu doživjeli su Ebu Bekr, Omer i Alija, r.a., pa je Omer rekao: „Ja sam i ovaj imetak, imetak države, kao staratelj jetima, ako budem bogat ustegnuću se a ako budem siromašan uzeću ga koliko mi bude potrebno." Dakle, državni službenici trebaju da slijede spomenute uzore i trebaju da se boje Boga kada je u pitanju državna imovina i da ne daju prednost rođacima, zetovima, prijateljima i

\footnotetext{
${ }^{41}$ Bilježe ga Buharija i Tirmizi.

${ }^{42}$ Bilježi ga Bejheki. Vidi: El-Munteka minet-tergibi vet-terhibi, hadis br. 2018.
} 
potrčkama. Mnogi vladari i predsjednici misle da je državna imovina njihovo vlasništvo i da imaju pravo njome raspolagati kako hoće i umiju. $\mathrm{Na}$ neke stvari se državna imovina troši bez ikakvog ograničenja (mediji, sport, državnu bezbjednost), dok se na drugoj strani škrtari i trošenje ograničava do krajnjih granica (obrazovanje, zdravstvo, prijevoz, infrastruktura)

Šerijat obavezuje balansiranje između interesa koji preferiraju nužne nad potrebnim, potrebne nad poželjnim. Preferiranje onoga što koristi većini ljudi nad onim što koristi grupi ljudi, ono u čemu je interes slabih i nemoćnih nad onim u čemu je interes oholih i bogatih.

\section{Socijalna solidarnost je vjerska obaveza}

Islam traži od svakog koji je u mogućnosti raditi da radi i da mu se pomogne u poslu kako bi mogao od plodova svog rada zbrinuti sebe $\mathrm{i}$ porodicu. Međutim, među ljudima ima i nemoćnih koji ne mogu raditi, a nemaju izvor prihoda. Isto tako ima i onih koji su sposobni za posao, ali posla nema, niti im država obezbjeđuje odgovarajući posao. Među njima ima i radnika kojima nije dovoljan prihod kojeg zarade zbog mizernosti, mnogobrojnosti porodice ili skupoće života. Pitanje je kako islam tretira navedenu populaciju? Da li ih ostavlja avetima siromaštva i potrebe ili iznalazi rješenje za njihove probleme? Uistinu, islam takve ne ostavlja nevolji i siromaštvu, nego im obezbjeđuje pristojan život, slijedeći metode:

\section{1- Izdržavanje bližnje rodbine}

Islam je propisao da bogat rođak treba izdržavati siromašnoga radi održavanja rodbinske veze i izvršavanja svoje obaveze: Daj bližnjem svome pravo njegovo, i siromahu, i putniku, ali ne rasipaj mnogo. (El-Isra, 26.) Ukoliko rođak svoju obavezu ne izvrši dobrovoljno, prisilit će ga islamsko sudstvo. Islamski pravnici su detaljno obrazložili pitanje međurodbinskog izdržavanja, njegove uvjete, iznos, čija je to obaveza i prema kome. O tome se može detaljnije pročitati u islamskim pravnim djelima o izdržavanju. 


\section{2- Zekat}

Zekat je imovinsko-socijalna obaveza koja se smatra trećim temeljem islama. Ko je zabrani iz škrtosti, od njega će se silom uzeti i sankcionisati ga diskrecionom kaznom - ta'zirom. Ako se radi o naoružanim obveznicima koji odbiju dati zekat, protiv njih će se povesti borba sve dok ne pristanu dati je. Ko zaniječe njenu obligatnost i ne bude odskora primio islam, smatrat će se otpadnikom od vjere. Zekat nije poklon ili milostinja koju bogataš daje iz samilosti siromašnom, nego je to određeno pravo koje država prikuplja i posredstvom svojih službenika dijeli onima kojima pripada. Stoga je Poslanik, a.s., opisao zekat riječima: „On se uzima od njihovih bogataša i dijeli njihovim siromasima." Dakle, zekat je porez koji se uzima, a ne dobrovoljni prilog. On se razlikuje od mnogih poreza koji se uzimaju od iscrpljenih i umornih radnika, malih trgovaca i službenika da bi se trošili na raskoš vladara. Za takav porez se s pravom može reći da se uzima od siromaha i daje bogatima.

Zekat se daje od ummeta ummetu, iz ruke koja posjeduje onoj ruci koja je potrebna. Te dvije ruke, ona koja daje i ona koja uzima, su u stvari dvije ruke jedne ličnosti, a to je islamski ummet. ${ }^{43}$ Zekat je obavezno dati na svaku imovinu koja se oplođuje, ako je dostigla nisab, pregodinila i nije opterećena dugom. Takva imovina je: stoka koja se drži na paši, novac i trgovačka roba. Po pitanju usjeva i plodova dužnost je dati zekat pri ubiranju i žetvi, a kada su u pitanju rude i skriveno blago, zekat se daje pri njihovom pronalasku. Islam nije propisao veliki procent zekata, stoga većina ummeta učestvuje u njegovom izvršenju. On se kreće od 2,5 posto na novac i trgovačku robu, od 5 posto na poljoprivredne proizvode koji se mehanički napajaju, deset posto na proizvode koji se natapaju kišom i do dvadeset posto na skriveno blago i rude. Dakle, sve što je čovjekov trud veći, procent zekata je manji i obratno.

\section{3- Drugi izvori državnih prihoda}

Ukoliko zekat ne bude dostatan da podmiri sve siromašne, aktivirat će se ostali državni pohodi kako bi se pokrile osnovne životne potrebe. Tu se

${ }^{43}$ Vidi: Mahmud Šeltut, El-Islam-akideten ve šeri'aten. 
prije svega misli na petine od ratnog plijena, harača, itd. Uzvišeni je rekao: I znajte da od svega śto u borbi zaplijenite jedna petina pripada Allahu $i$ Poslaniku, i rodbini njegovoj, i siročadi, i siromasima, i putnicima... (ElEnfal, 41.) Plijen od stanovnika sela i gradova koji Allah Poslaniku Svome daruje pripada: Allahu i Poslaniku Njegovu, i bližnjim njegovim, i siročadi, i siromasima, i putnicima - da ne bi prelazilo iz ruku u ruke bogataša vaših. (El-Hašr, 7.) Kod pokrivanja potreba siromašnih, mogu učestvovati i ostali državni resursi: nafta, ruda, poljoprivredna zemljišta, nekretnine, itd. Država u islamu nije odgovorna samo za zaštitu i sigurnost, nego i za zbrinjavanje slabih i potrebnih, kao i za obezbjeđenje dostojnog života. U jednom hadisu stoji: „Svi ste vi pastiri i bićete pitani za svoje stado...Vladar je pastir i odgovaran je za svoje stado....." ${ }^{44} \mathrm{Na}$ taj način Poslanik, s.a.v.s., je objasnio odgovornost svih i da je on - Poslanik, a.s., preči vjernicima od njih samih. Ko ostavi imovinu iza sebe pripada njegovim nasljednicima, a ko ostavi dug ili nezbrinutu maloljetnu djecu, ona pripadaju njemu. ${ }^{45}$

Prema Omeru, r.a., svako ima pravo na državnu imovinu. Stoga je dao Jevreju plaću iz državne kase, kada ga je vidio da na vratima prosi. Svakom novorođenčetu je odredio dječiji doplatak koji se povećavao proporcionalno njegovom rastu i starosti.

\section{4- Druga prava u imovini}

Ukoliko zekat i ostali državni prihodi ne budu dovoljni da obezbijede normalan život siromasima, bogataši su dužni da im to obezbijede. Nije vjernik onaj koji zanoći sit, a njegov komšija je gladan, nije vjernik onaj koji svom bratu ne želi ono što želi sam sebi. Ukoliko bogataši dobrovoljno pomognu siromasima na poticaj svog imana i bogobojaznosti, to će bez sumnje biti dobro. Poslanik, a.s., nam je rekao za Eš́arijin sljedeće: „Eš'arije kada im neko pogine u borbi i ostanu im udovice, ili kada im se smanji hrana kod porodica u Medini, sakupe sve što imaju kod sebe na

\footnotetext{
${ }^{44}$ Muttefekun alejhi od Ibn Omera.

${ }^{45}$ Vidi: Sahibul-Džami'i, hadisi broj: 1453-1456.)
} 
jedan čaršaf, a zatim to međusobno pravedno podijele. Oni su od nas i mi smo od njih. “46

Ukoliko bogati dobrovoljno ne zbrinu siromašne svoga kraja, vladar je dužan da ih obaveže da to urade. Od Poslanika, s.a.v.s., se prenosi da je rekao: „U imovini ima obaveza mimo zekata.“ A Kur'an na to ukazuju u sljedećem ajetu: Čestiti su oni koji vjeruju u Allaha i u onaj svijet, i u meleke, i u knjige, i u vjerovjesnike, i koji od imetka, iako im je drag, daju rodacima, $i$ siroćadi, $i$ siromasima, i putnicima, i prosjacima, $i$ za otkup iz ropstva, i koji molitvu obavljaju i zekat daju... (El-Bekare, 177.) Citirani ajet je napravio razliku između imetka koji se daje rođacima i zekata, te ukazuje na to da su to dva različita imovinska prava. Zekat je utvrđeno i određeno periodično pravo, dok su ostala prava nalaže potreba i interes; nisu određena niti vremenski ograničena. Ako ljudi imovinske obaveze ne izvrše dobrovoljno, bit će prisiljeni izvršiti ih. Osman, r.a., je rekao: „Allah doista putem vlasti čini više nego putem Kur'ana. " ${ }^{47}$

\section{5- Dobrovoljni prilozi - sadake}

Islam se pri realizaciji socijalnog sistema ne oslanja samo na obavezne zakone i obligatna prava, nego podstiče muslimana na dobrovoljna davanja. Dobrovoljno trošenje devalvira imetak i ovaj svijet, upozorava na škrtost i egoizam i čini dragim tajno i javno dijeljenje, kao i dijeljenje noću i danju, u izobilju i neimaštini. Također, obećava protunaknadu na ovom svijetu, a nagradu na onom. Šejtan vas plaši neimaštinom i navraća vas da budete škrti, a Allah vam obećava oprost i nagradu Svoju. (El-Bekare, 268.) Reci: "Gospodar moj daje obilnu opskrbu onome kome hoće od robova Svojih, a kome hoće uskraćuje; što god vi udijelite, On će to nadoknaditi, On najbolje opskrbljuje." (Sebe', 39.) Oni koji udjeljuju imanja svoja i noću i danju, tajno i javno, dobiće nagradu od Gospodara svoga; i ničega se oni neće bojati i ni za čim oni neće tugovati. (El-Bekare, 274.)

\footnotetext{
${ }^{46}$ Bilježe ga Buharija i Muslim od Ebu Muse. Sahihul-Džami'u, hadis br. 1852.

${ }^{47}$ Karadavi, Melamihul-mudžtemi'il-islami, str. 230.
} 


\section{Dobrotvorni vakuf i trajna sadaka}

Islam najviše podstiče na trajnu sadaku - sadaku koja ostaje i nakon smrti njenoga darovatelja. Takav postupak jasno se objelodanjuje kroz sistem dobrotvornog vakufa. To je vakuf u kojem imovina izlazi iz vlasništva vlasnika da bi se njeni plodovi i koristi usmjerili na neku dobrotvornu svrhu, tražeći na taj način Allahovo zadovoljstvo. Allahov Poslanik, s.a.v.s., preporučio je Omeru, r.a., da uvakufi svoju imovinu u Hajberu. Nije bilo nijednog asbaha bez imovine, a da nije dio nje uvakufio. Proučavajući razloge uvakufljenja i uvjete vakufa jasno se otkriva bit i suština solidarnosti u islamskom društvu. Ona je utemeljena na osjećajima prema dobrome, ljubavi prema samilosti, dobročinstvu i širokoj rasprostranjenosti plemeniti ljudskih osjećaja. Njegovo dobročinstvo nije se zadržalo samo u dušama čovjeka, nego je prešlo na samilost i ljubav prema životinjama. ${ }^{48}$

\section{Solidarnost među generacijama}

Postoji i vremenska solidarnost koju mnogi i ne primjećuju, a stoji uporedo sa mjesnom i naziva se solidarnost među generacijama. Pod generacijskom solidarnosti se misli na iskorištavanje prirodnih resursa od strane jedne generacije. Prema tome, jedna generacije ne bi smjela prigrabiti sve za sebe, a ništa ne ostaviti onima poslije nje. Dužnost postojeće generacije je da vodi računa o budućoj i da se odnosi prema njoj kao brižni otac. Sadašnja generacija treba da bude umjerena u potrošnji i iskorištavanju prirodnih resursa, tako da i budućim generacijama ostanete nešto što će im koristiti. Poslanik, a.s., je rekao: „Da ostaviš svoje nasljednike bogatim bolje ti je nego da ih ostaviš siromašnim i da prose od ljudi. “49 Također, se prenosi da je Ebu Bekra, r.a., rekao: „Ne divim se čovjeku koji za jedan dan pojede hranu za nekoliko dana. “50 Isto se to može reći i za društvo ili zajednicu koja za vrijeme jedne generacije pojede nafaku

\footnotetext{
${ }^{48}$ Vidi poglavlje o samilosti iz djela Karadavi, El-Iman vel-haja.

${ }^{49}$ Muttefekun alejhi od S'ada.

${ }^{50}$ Karadavi, Malamihu mudžteme'il-islami, str. 232.
} 
budućim generacijama. Upravo je to bio Omerov, r.a., motiv da ne pristane podijeliti plodnu zemlju Iraka onima koji su je osvojili. Tu se radilo o velikom bogatstvu u kojemu bi uživala pobjedonosna generacija, a buduće ne bi imale ništa iz čega bi se izdržavale, obučavale i ispunjavale svoje potrebe. Stoga je Omer, r.a., govorio svojim neistomišljenicima: ” Zar želite da dođu ljudi poslije vas i da ne imadnu ništa?!"Svoje mišljenje je opravdavao sljedećom izjavom: „Ja želim stvar koja će biti dovoljna i prvim i potonjim generacijama." Opravdanje za svoj stav našao je i u suri El-Hašr koja nalaže da se plijen podijeli između buduće i postojeće generacije muhadžira i ensarija. Oni koji poslije njih dolaze - govore: "Gospodaru naš, oprosti nama i braći našoj koja su nas u vjeri pretekla... (ElHašr, 10.)

$\mathrm{Na}$ taj način generacije se solidarišu i potpomažu, a ne proklinju prethodne, govoreći: Sve su nam uzeli, a da nam ništa nisu ostavili. Treba voditi računa o tome da se takvo što ne desi u zemljama izvoznicima nafte. Sadašnja generacija potroši sve u raskoš, prekomjerno crpi naftu, tako da je njena ponuda na svjetskom tržištu postala prevelika, pa se zbog toga prodaje ispod cijene. Da misle na potonje generacije i njihova prava suzdržali bi se u tome, bili bi umjereniji i ne bi rasipali, jer Allah ne voli rasipnike.

\section{Smanjenje razlika među staležima}

Islam je priznao međuljudske različitosti po pitanju imovine i nafake, jer se ljudske prirode razlikuju po inteligenciji, ljepoti, snazi i ostalim individualnim nadarenostima. Stoga ne čudi da se ljudi razlikuju po iznosu imetka i bogatstva. Uzvišeni je rekao: Allah opskrbljujući vas daje jednima više nego drugima. (En-Nahl, 71.) Ta različitost ili nejednakost nije besmislena i badava, nego sukladna mudrosti na osnovu koje se život uređuje i pravedno odvija. Uzvišeni je rekao: Zar oni da raspolažu milošću Gospodara tvoga? Mi im dajemo sve što im je potrebno za život na ovome svijetu i Mi jedne nad drugima uzdižemo po nekoliko stepeni da bi jedni druge služili. (Ez-Zuhruf, 32.) Pod potčinjavanjem ne misli se na potčinjavanje sili, nego sistemu i redu. Život je poput velike fabrike u kojoj rade i nadležni i podložni, inženjeri i radnici, čuvari i sluge. Svako je ima svoju 
zadaću kada je u pitanju njeno normalno funkcionisanje i proizvodnja. I pored toga što je islam priznao načelo različitosti $u$ nafaki i neravnomjernost u bogatstvu i siromaštvu, on ipak nastoji približiti razlike među staležima ograničavanjem nesrazmjernosti bogatstva i uzdizanjem stepena siromaštva. Islam prezire da se imetak nalazi u određenom broju ruku, dok je većini zabranjeno da uživa njegove plodove. Da bi se spriječilo gomilanje imetka bogatašima, islam nalaže nekoliko sredstava:

1- Obavezivanje bogatih da svoju imovinu ne oplođuju na zabranjen način (kamatom, monopolom, prevarom, trgovinom). Ovo ograničenje pri investiranju imetka uveliko zatvara put ka enormnom bogaćenju.

2- Uzimanje dijela imovine bogataša i davanje siromašnim. Zekat je sredstvo dato siromahu u količinama koje su dovoljne putem mjesečnog davanja ili trajnog zbrinjavanja. Imam Nevevi je rekao: „Siromašnom i potrebnom se daje onoliko koliko im je potrebno radi anuliranja njihova nezavidna stanja kako bi bili zbrinuti za stalno. To zbrinjavanje zavisi od čovjeka do čovjeka i od mjesta do mjesta. Zanatliji je potreban alat, stoga će mu se dati da zarađuje s njim.

3- Propisivanje bogatašima imovinskih obaveza mimo zekata: izdržavanja rodbine, zavjeta, otkupa, kurbana, komšijskih prava, prava gosta, hranjenja gladnih, pomoći nevoljniku, oslobađanje roba, liječenje bolesnika, pomoć u prirodnim katastrofama (ratovi, glad). U hadisu stoji: „Ne vjeruje u mene ko zanoći sit a njegov komšija je pored njega gladan a on to zna." ${ }^{\text {51 }}$

4- Nasljedstvo koje je islam propisao djeci, roditeljima, ženama, agnatima i kognatima pod određenim uvjetima uveliko je faktor sitnjenja imovine i njene raspodjele nakon smrti ostavitelja. Nasljedstvo se dijeli na veliki broj nasljednika za razliku od nekih drugih sistema koji ga ograničavaju na najstarijeg sina. Pod mirazom podrazumijeva se oporuka za one koji nisu nasljednici. Neki učenjaci smatraju je obaveznom na osnovu riječi Uzvišenog: Kada neko od vas bude na samrti, ako ostavlja imetak, propisuje vam se, kao obaveza za one koji se Allaha boje, da pravedno učini oporuku roditeljima i bližnjima. (El-Bekare, 180.) Iz ove vrste oporuke izvedena je

${ }^{51}$ Karadavi, Fikhuz-zekat, 2/572-275., osmo izdanje, knjižara Vehbe. 
obavezna koja nastoji unucima zaštiti nasljedstvo kada im očevi umru za života njihovih djedova.

5- Pravo nadležnih da naprave rebalans ili preraspodjelu budžeta posredstvom društvene imovine - ratnog plijena, a ne putem uzurpacije legalne imovine čiji vlasnici se pri njenom korištenju pridržavaju šerijatskih propisa. Tako je postupio Poslanik, a.s., kod podjele ratnog plijena plemena Beni Nadir: plijen je podijelio samo muhadžirima i dvojici ensarija koji su bili u veoma teškom materijalnom stanju. Muhadžiri su napustili svoja imanje i kuće, stoga je imovinska razlika između njih i ensarija bila ogromna. Ensarije su posjedovali kuće i nekretnine, a muhadžiri skoro ništa. Izjednačenost koju islam zagovara je prvom prilikom uspostavljena od strane Poslanika, a.s. nakon čega je Kur'an potvrdio Poslanikov, a.s., postupak, razlažući podjelu ratnog plijena:

Da ne bi prelazilo iz ruku u ruke bogataša vaših. (El-Hašr, 7.)

Iz ovog Poslanikovog, a.s., postupka musliman-vladar može za siromahe odrediti posebnu imovinu iz državne kase kako bi smanjio staleške razlike i realizovao ekonomsku uravnoteženost u islamskom društvu i zajednici.

\section{Islam i savremeni ekonomski sistemi}

Iz navedenih načela i principa uočavamo da je islamska ekonomija drugačija od savremenih. To su prije svega kapitalistička i komunistička ekonomija. Islamska ekonomije je dvanaest stoljeća u svom nastanku pretekla navedene ekonomije.

\section{Islam i kapitalizam}

Kapitalizam počiva na svetosti lične slobode i nastojanju da ne bude ograničena, te da pojedincu omogući trošenje imovinu bez ikakvih posebnih ograničenja. U takvom društvu i zajednici ne postoji interna samokontrola koja bi učinila da se to pravo poštuje i štiti, nego se njime manipulira. Islam stavlja ograničenja na posjedovanje, privređivanje, oplođavanje i potrošnju. Propisuje stalne i privremene obaveze vlasniku imovine. Anulira legalnost, kamatu, monopol, prevaru. Odbacuje sve što ne priliči moralu i što je oprečno sa općim interesom ljudi. Kod muslimana 
ta prava čuva savjest, jer su mu propisana od istinskog vlasnika imovine Uzvišenog Allaha, dž.š.

Islam je dao pravo da se uzurpira privatna imovina ukoliko je oprečna sa općim interesom društva, te da se rasipniku blokira pravo na raspolaganje privatnom i društvenom imovinom.

\section{Islam i komunizam}

Ako kapitalizam drži svetim lične slobode, komunizam ima drugačiji pogled:

a- Potpuno devalvira vrijednost pojedinca i njegove slobode. Smatra ga običnim šarafom u državnom aparatu. Komunizam posvećuje društvo koje predstavlja državu. Pojedinac nema pravo na zemlju, fabriku, nekretninu ili bilo koje drugo sredstvo za sticanje imovine. Dužan je raditi za državu kao najamnik, a ona posjeduje sve izvore proizvodnje i upravljanje njima. Islam ne pravi razliku između sredstava proizvodnje i ostalih njenih faktora i između velike i male imovine ukoliko je stečena na halal - dozvoljen način.

b- Filozofija komunizma počiva na borbi protiv staleža i potpaljivanju vatre među njima Komunizam koristi krvava sredstva nasilja, dok ne poništi sve staleže osim jednog - proletarijata/ radničkog staleža. Zapravo ne pobjeđuje stalež radnika, nego grupa vještih partijskih i vojnih službenika koji u ime radnika preuzimaju vlast i zabranjuje sve. Marksistička parola bila je: Radnici svijeta ujedinite se protiv drugih staleža! $S$ druge strane počiva na filozofiji širenja bratstva među ljudima, podstičući na pomirenje. Velika je razlika između onoga koji upućuje poziv radnicima da se ujedine protiv drugih i onoga koji upućuje poziv svim ljudima da se pobratime i međusobno vole: „Budite Allahovi robovi braća.“52

c- Dijalektički socijalizam stalno prate politički pritisak, ideološki terorizam, sputavanje sloboda, gušenje oporbe. Bilježi se da je Lenjin jedne

${ }^{52}$ Bilježi ga Muslim od Ebu Hurejre. Vidi: Sahihul-Džami'us-Sagir, hadis br. 7142. 
prilike rekao svom prijatelju da ne smeta ubiti tri četvrtine čovječanstva, ako će četvrti dio biti socijalistički - komunistički.

Islam počiva na dogovaranju - šuri, a savjetovanje vladara je dio vjere. Građani se podučavaju na dobro, na sprečavanje zla i upozoravanje ummeta na Allahovu kaznu ukoliko se ne suprotstavi nasilju i nasilniku.

\section{Cilj i važnost islamske ekonomije}

Koliko se god islam od navedenih svjetovnih ekonomskih sistema razlikuje po pitanju lične slobode i opće koristi, razlikuje se i po suštini, osnovi, cilju, pravcu, bitnosti i zadaći.

a- Osnovu na kojoj počiva islamski sistem nije postavio čovjek, nego ga je propisao Allah. On je Gospodar svih i propisuje bez ikakve nepravde i pristranosti. On je Gospodar bogatih i siromašnih, radnika i poslodavaca. Milostiviji je prema njima od majke prema svome djetetu. Kada im propiše neki sistem nema pravednijeg, potpunijeg i savršenijeg od njega, za razliku od svjetovnih sistema koji su produkti nesavršenih ljudi.

b- Svi ti sistemi su čisto materijalistički; ovaj svijet smatraju svojom brigom, a krajnji cilj im je materijalna raskoš. To im je ujedno i njihov Firdevs. U islamu je ekonomija sredstvo kojim se postiže veliki cilj - da ljude ne opterećuje briga o životu i borba za hljeb. Treba raditi za spoznaju Allaha i lijepog odnosa sa Njim. Sigurnost i osnovni životni uvjeti smire čovjeka i okrenu ga ka skrušenosti i obožavanju Gospodaru. Koji ih gladne hrani i od straha brani. (Kurejš, 4.) Nakon toga će osjetiti čvrste bratske veze koje ih povezuju sa drugim Božijim robovima.

c- Svjetovni ekonomski sistemi su odvojeni od morala i moralnih vrijednosti. Islam zanemaruje ciljeve oprečne sa moralom i moralnim vrijednostima.

Stoga je islam nevjernicima zabranio hadždž, kao i da nagi tavafe oko Kabe bez obzira što je taj vjerski turizam donosio korist. Uzvišeni u tom smislu veli: $O$ vjernici, mnogobošci su sama pogan, i neka više ne dolaze na haď̌ 
Svetome hramu poslije ovogodišnjeg hadža. A ako se bojite oskudice, pa Allah će vas, ako hoće, iz obilja Svoga imućnim učiniti. - Allah zaista sve zna $i$ mudar je. (Et-Tevbe, 28.) Ako otvaranje kockarnica, kladionica, javnih kuća i noćnih klubova ostvaruju ekonomsku korist, takva korist po šerijatu se ne uvažava, jer je oprečna njegovim principima po pitanju zaštite i zdravlja razuma, tijela, morala, akaida i međuljudskih odnosa. Kur'an je zabranio vino i kocku zbog velikog grijeha kojeg involviraju, ne uzimajući u obzir ekonomsku korist koju neki ljudi imaju od toga. Pitaju te o vinu $i$ kocki. Reci: "Oni donose veliku štetu, a i neku korist ljudima, samo je šteta od njih veća od koristi." (El-Bekare, 219.)

Dakle, islamski ekonomski sistem se razlikuje od kapitalizma, jer pretjeruje po pitanju individualnih prava i uvažava ih bez ikakvih ograničenja. Razlikuje se i od komunizma koji pretjeruje u devalviranju pojedinca na račun općeg interesa. Dakle, prvi sistem preferira pojedinca nad interesom zajednice, a drugi zajednicu nad interesom pojedinca. Oba sistema daju prednost ovome svijetu nad onim, tijelu nad dušom. Jedino islam je čist od zastranjenja i balansira između prava i obaveza, pojedinca i zajednice, duše i tijela, ovoga i onoga svijeta bez ikakvog pretjerivanja ili ustupanja. Da ne prelazite granice u mjerenju - i pravo mjerite i na teraziji ne zakidajte! (Er-Rahman, 8-9.)

\section{Umjesto zaključka}

Svi ekonomski sistemi, primjenjivani kroz historiju ljudskog roda imali su za cilj usrećiti čovječanstvo i donijeti mu ekonomski mir, izobilje i stabilnost. Međutim, to se nije desilo. I pored toga čovjek i dalje traga, ne gubeći nadu da će nekada postići te ciljeve. Čovjek optužuje sebe za neuspjeh, a rijetko ekonomske sisteme koji su bili u većini slučajeva glavni krivci. Islam je prirodna vjera - vjera srednjeg puta, objavljena kao Božija uputa za sreću na ovome i spas na onome svijetu. To je vjera čiji propisi i norme uvažavaju sve ljudske potrebe, kanališu ih i usmjeravaju ka dobru. Tu spadaju propisi i norme iz islamske ekonomije. One su date sukladno nagonima, potrebama i interesima ljudi od strane Onog ko ih je stvorio. Njihova primjena zadovoljava sve te potrebe, donoseći sreću ljudima vjernicama na ovome i spas na onome svijetu. Ona ima budućnost jer 
može uistinu obezbijediti ljudima njihove materijalne potrebe, osigurati pristojan život, smanjiti stalešku razliku između bogatih i siromašnih, zavidnost i netrpeljivost zamijeniti sa bratskom ljubavi, balansirati opće i posebne interese, dati iste prilike svima. Jedina je putem svojih principa $\mathrm{i}$ normi uvažila cijelu ljudsku prirodu i potrebe, a svaki sistem koji zanemaruje i ignorira ljudsku prirodu unaprijed je osuđen na neuspjeh i nestanak.

\section{Literatura:}

1. Kur'anul-kerim, prijevod kur'anskih ajeta uzet je iz The Zekr projekt.

2. Abdulbaki, Muhammed Fuad, El-Lu'lu vel-merdžani fima ittefeka alejhi šjhani, daru ihjail-kutubil-arabijje.

3. Albani, Nasiruddin, Sahih va daif El-Džami's-sagir ve zijadetuhu, elmetebul-islami, Bejrut.

4. Bejheki, Ebu Bekr Ahmed b. Husejn, Es-Sunenul-kubra, prvo izdanje, 1344.h. Medžlis dairetil-me'arif en-nizamijje, Hajderabad, Indija.

5. El-Bejheki, Ebu Bekr, Ahmed b. Husejn, El-Džamiu' li šu'abil-imani, mektebetur-Ruśd, prvo izdanje, Rijad 2003.

6. Ibn Hadžer, Fethul-Bari šerh Sahihil-Buhari, darul-fikr.

7. Hakim, Ebu Abdullah b. Abdullah, El-Mustedrek ala sahihajni, Mektebetu metabi'in-nasril-hadise, Rijad.

8. Hanbel, Ahmed b. Hanbel b. Ahmed, Es-Sunen, tahkik: Šuajb Arnaut, prvo izdanje 1997., muessesetur-risale, Bejrut - Liban,

9. Hanbel, Ahmed, El-Musned ve bihamišihi Muntehabu kenzil-ummali fi sunenil-akvali vel-efa'li, el-mektebul-islami.

10. Hejsemi, Nuruddin Ali b. Ebi Bekr, Medžme'uz-zavaid ve menbe'ilfevaid, darul-fikri, Bejrut 1412.h.

11. Karadavi, Jusuf, Melamihul-medžtemi'il-islami, mektebetu Vehbe, prvo izdanje,1993., Kairo.

12. Karadavi, El-Imanu vel-hajatu, daruz-zehai'r, osamnaesto izdanje 1996., Demmam, S. Arabija.

13. Karadavi, Fikhuz-zekat, 2/572-275., osmo izdanje, knjižara Vehbe 
14. Ragib, Ebul-Kasim b. Mufeddal b. Muhammed, Ez-Ziri'atu ila mekarimiš-šseri'a, str. 380-381.,verifikacije: Ebul-Jezid El-'Adžmi, Izdavač: Darus-sahve, Egipat

15. Šeltut, Mahmud, El-Islamu akideten ve šeriaten, daruš-šuruk, Kairo 2007.

16. Taberani, Ebul-Kasim Sulejman b. Ahmed, El-Mu'džemul-evsati, darulharemejni, Kairo 1415.h.

17. Tirmizi, Ebu Isa, Muhammed b. Isa, Senenut-Tirmizi, darul-hadis.

18. Ibn Tejmijje, Tekjuddin, Es-Sijasetuš-šeri'jje fi islahir-rai' ver-reijjeh, prvo izdanje 1992. Darul-afakil-džedide, Bejrut, Liban. 
Sulejman Topoljak, $\mathrm{PhD}^{53}$

\section{BASIC PRINCIPLES AND TERMS OF ISLAMIC ECONOMY}

\section{Abstract}

Material prosperity of each nation and every individual represent the goals of every economic system and state. Only nations that have accommodated basic living conditions can think about higher goals and strategies. One of the main intentions of Islam is providing a legal reproduction of the human race, the protection of the life on Earth and providing a man, as a God's representative in the cosmos, a suitable life, a life that corresponds with his position and that will help him to carry out his task for which he was sent and lives on this planet. Since these objectives cannot be achieved without an economic system, it is understandable that Islam has its own economic system and its instruments through which these goals can be realized. Given the importance of the economic system in Islam, and given the rule that means acquire the status of objectives, I have chosen to briefly address the basic principles and norms of Islamic economic system as a subject of my work. The aim of the study is to give and explain the basic principles of Islamic economics in a completely clear and easy way, to elaborate its purpose and characteristics in comparison to the other two most famous economic systems that were administered or are still applied in the modern world. At the same time, the study sought to implicitly and sometimes explicitly point out the shortcomings and the reasons for which the economic systems implemented in the past did not bring material well-being and happiness to the mankind, and who are at the same time avoided or involved in the Islamic economic system. This gives an Islamic economic system a bright future and relevance which can be accepted by all and can make everyone satisfied.

Keywords: Islam, economy, solidarity, Haram, Halal, earnings, assets, property

${ }^{53}$ Islamic Pedagogical Faculty in Bihac. 
الأستاذ الدكتور سليمان توبولياك؛ه

\section{مبادئ الاقتصاد الإسلامي الأسـاسية}

\section{الخلاصية}

يسعى كل نظام اقتصادي أو دولة إلى رقي مادي لأية أمة أو فرد. الشعب الذي يتم تأمين ظروف معيشته الأساسية هو وحده يمكن أن يفكر في أهدافه العليا وإستراتيجيته.

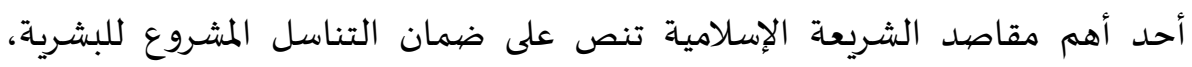

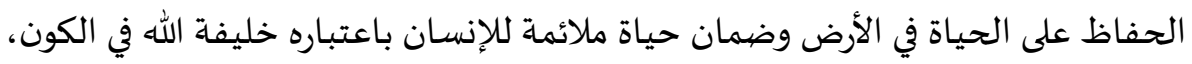

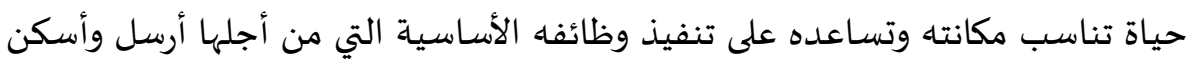
في الأرض. بما أن تلك الأهداف لا يمكن تحقيقها من دون نظام اقتصادي، فإنها من

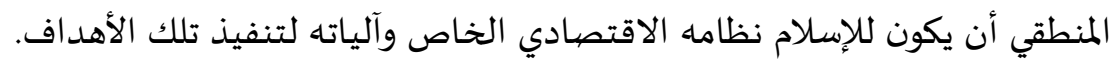

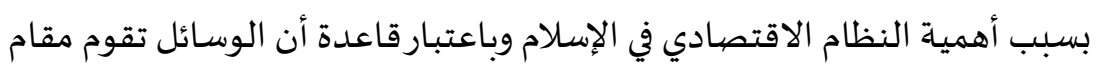

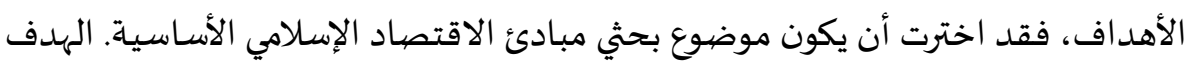
من البحث أن أذكروأوضح وبطريقة سهلة وسلسة مبادئ الاقتصياد الإسلامي الأساسية:

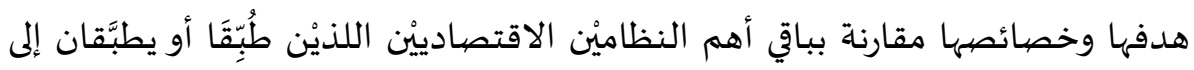

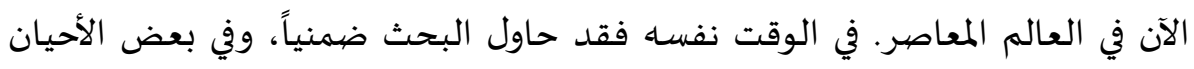

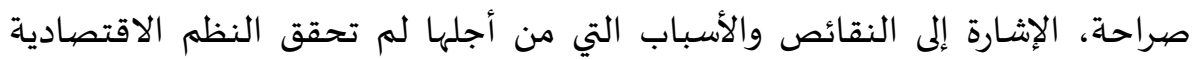

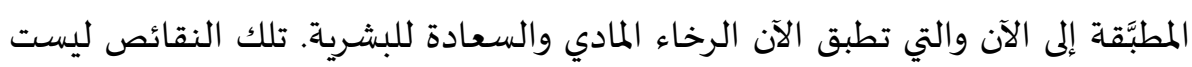

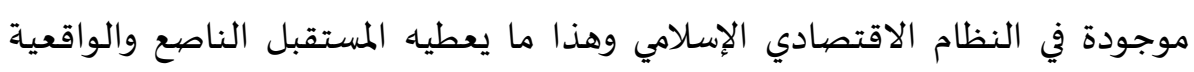
ليمكن تقبله من قبل الجميع وليسعد الجميع بتطبيقه.

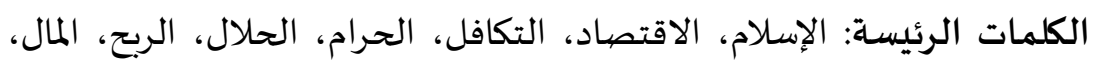

الملكية

\&ه كلية التربية الإسلامية بجامعة بهاتش 